\title{
geodiversitas
}

\section{A review of fossil Bursidae and their use for phylogeny calibration}

Malcolm T. SANDERS, Didier MERLE \& Nicolas PUILLANDRE
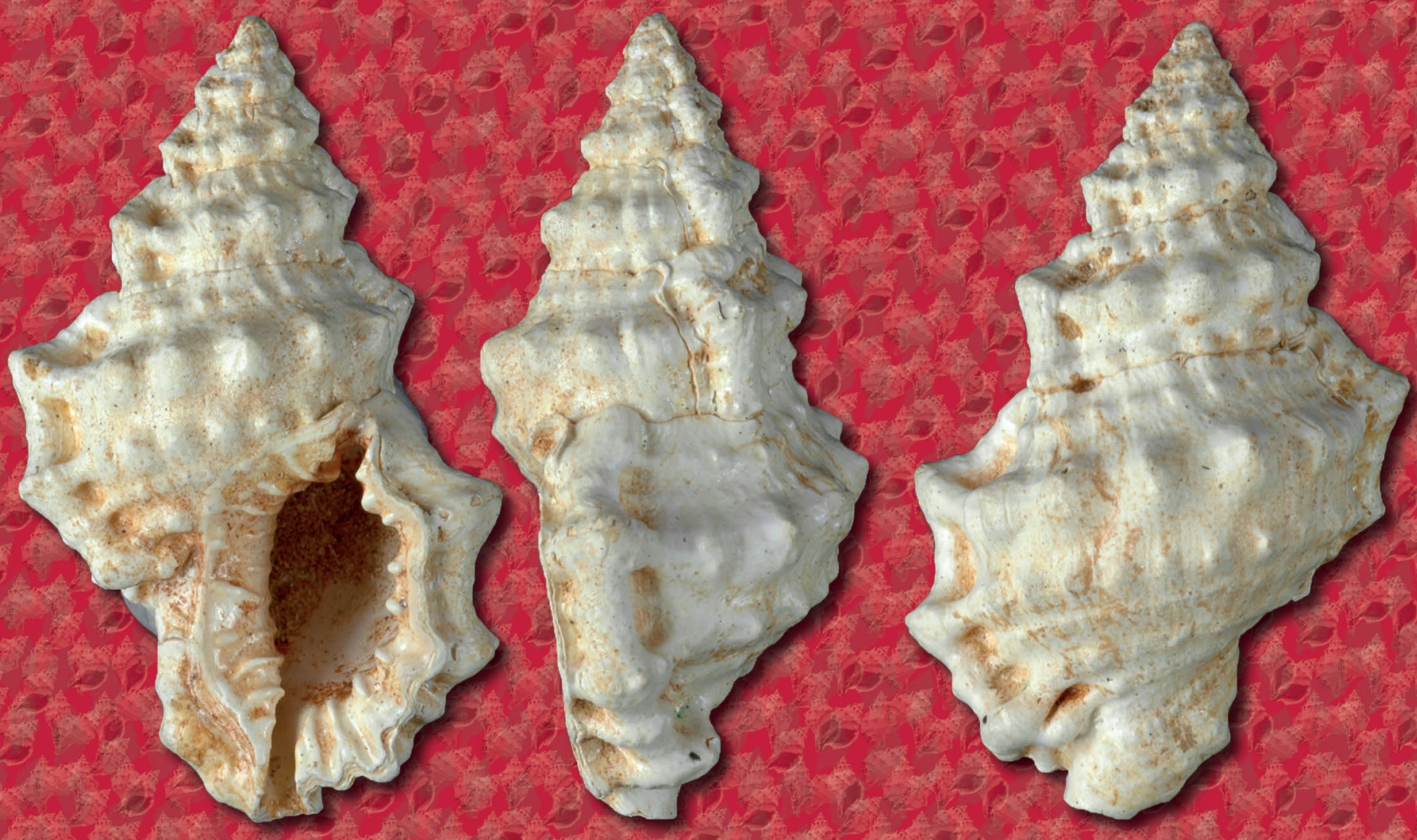

MUSEUU 
DiRECTEUR DE LA PUBLICATION: Bruno David,

Président du Muséum national d'Histoire naturelle

RÉdACTEUR EN CHEF / EDITOR-IN-CHIEF: Didier Merle

ASSISTANTS DE RÉDACTION / AsSISTANT EDITORS: Emmanuel Côtez (geodiv@mnhn.fr); Anne Mabille

Mise EN PAGE / PAGE LAYOUT: Emmanuel Côtez

COMITÉ SCIENTIFIQUE / SCIENTIFIC BOARD:

Christine Argot (MNHN, Paris)

Beatrix Azanza (Museo Nacional de Ciencias Naturales, Madrid)

Raymond L. Bernor (Howard University, Washington DC)

Alain Blieck (chercheur CNRS retraité, Haubourdin)

Henning Blom (Uppsala University)

Jean Broutin (UPMC, Paris)

Gaël Clément (MNHN, Paris)

Ted Daeschler (Academy of Natural Sciences, Philadelphie)

Bruno David (MNHN, Paris)

Gregory D. Edgecombe (The Natural History Museum, Londres)

Ursula Göhlich (Natural History Museum Vienna)

Jin Meng (American Museum of Natural History, New York)

Brigitte Meyer-Berthaud (CIRAD, Montpellier)

Zhu Min (Chinese Academy of Sciences, Pékin)

Isabelle Rouget (UPMC, Paris)

Sevket Sen (MNHN, Paris)

Stanislav Štamberg (Museum of Eastern Bohemia, Hradec Králové)

Paul Taylor (The Natural History Museum, Londres)

COUVERTURE / COVER

Aquitanobursa tuberosa (Grateloup, 1833) n. comb., MNHN.F.A70285, Burdigalian of le Peloua, Staadt coll.

Geodiversitas est indexé dans / Geodiversitas is indexed in:

- Science Citation Index Expanded (SciSearch $\left.{ }^{\circledR}\right)$

- ISI Alerting Services ${ }^{\circledR}$

- Current Contents ${ }^{\circledR} /$ Physical, Chemical, and Earth Sciences ${ }^{\circledR}$

- Scopus ${ }^{\circledR}$

Geodiversitas est distribué en version électronique par / Geodiversitas is distributed electronically by:

- BioOne ${ }^{\circledR}$ (http://www.bioone.org)

Les articles ainsi que les nouveautés nomenclaturales publiés dans Geodiversitas sont référencés par / Articles and nomenclatural novelties published in Geodiversitas are referenced by:

- ZooBank ${ }^{\circledR}$ (http://zoobank.org)

Geodiversitas est une revue en flux continu publiée par les Publications scientifiques du Muséum, Paris Geodiversitas is a fast track journal published by the Museum Science Press, Paris

Les Publications scientifiques du Muséum publient aussi / The Museum Science Press also publish:

Adansonia, Zoosystema, Anthropozoologica, European Journal of Taxonomy, Naturae, Cryptogamie sous-sections Algologie, Bryologie, Mycologie.

Diffusion - Publications scientifiques Muséum national d'Histoire naturelle

CP $41-57$ rue Cuvier F-75231 Paris cedex 05 (France)

Tél. : 33 (0)1407948 05 / Fax: 33 (0)14079 3840

diff.pub@mnhn.fr / http://sciencepress.mnhn.fr

(C) Publications scientifiques du Muséum national d'Histoire naturelle, Paris, 2019

ISSN (imprimé / print): 1280-9659/ ISSN (électronique / electronic): 1638-9395 


\section{A review of fossil Bursidae and their use for phylogeny calibration}

Malcolm T. SANDERS

CR2P (CNRS, MNHN, UPMC, Sorbonne Université),

Département Origines et Évolution, Muséum national d'Histoire naturelle, case postale 38, 57 rue Cuvier, F-75231 Paris cedex 05 (France) and ISYEB (CNRS, MNHN, EPHE, Sorbonne Université), Institut Systématique Évolution Biodiversité, Muséum national d'Histoire naturelle, case postale 26, 57 rue Cuvier, F-75231 Paris cedex 05 (France) malcolm.t.sanders@gmail.com (corresponding author) https://orcid.org/0000-0002-8024-603X

Didier MERLE

CR2P (CNRS, MNHN, UPMC, Sorbonne Université), Département Origines et Évolution, Muséum national d'Histoire naturelle, case postale 38, 57 rue Cuvier, F-75231 Paris cedex 05 (France) didier.merle@mnhn.fr

Nicolas PUILLANDRE

CR2P (CNRS, MNHN, UPMC, Sorbonne Université), Département Origines et Évolution, Muséum national d'Histoire naturelle, case postale 38, 57 rue Cuvier, F-75231 Paris cedex 05 (France)

nicolas.puillandre@mnhn.fr https://orcid.org/0000-0002-9797-0892

Submitted on 28 May 2018 | accepted on 13 November 2018 | Published on 8 March 2019

urn:Isid:zoobank.org:pub:33E8EF32-4BE4-4992-9917-8611CA0AD579

Sanders M. T., Merle D. \& Puillandre N. 2019. - A review of fossil Bursidae and their use for phylogeny calibration. Geodiversitas 41 (5): 247-265. https://doi.org/10.5252/geodiversitas2019v41a5. http://geodiversitas.com/41/5

\section{ABSTRACT}

Bursidae Thiele, 1925 is a moderately diverse group of extant tonnoidean gastropods with a significant fossil record. We review the fossil record of the family. We exclude some taxa from Bursidae, particularly the most ancient ones: Hanaibursa aquilana (Parona, 1909) (Aptian) and Bursa saundersi Adegoke, 1977 (Selandian). We exclude the genus Olequahia Stewart, 1926; its posterior siphonal canal is not analogous with that of Bursidae. We also discuss the possible revision of the type genus, Bursa

KEY WORDS

Bursidae,

Tonnoidea,

node calibration, lectotypifications, new combinations, new genera. Röding, 1798, on the basis of previously published phylogenies; the genus is not monophyletic. We create two new genera, Olssonia n. gen. (type species: Bursa chira Olsson, 1930) and Aquitanobursa n. gen. (type species: Ranella grateloupi d'Orbigny, 1852), containing only fossil species. Lectotypes are designated for Ranella grateloupi d'Orbigny, 1852, Ranella morrisi d'Archiac \& Haime, 1853 and Apollon pelouatensis Cossmann \& Peyrot, 1924. Based on this revision of the fossil record, we propose five fossil calibration points that can be used to date molecular phylogenetic trees of Bursidae. 


\begin{abstract}
RÉSUMÉ
Révision des Bursidae fossiles et leur utilisation dans la calibration des phylogénies.

Les Bursidae Thiele, 1925 sont un groupe de Tonnoidea (Mollusca: Gastropoda) actuels modérément diversifiés possédant un registre fossile assez important. Dans ce travail nous faisons la revue de la totalité du registre fossile de la famille. Tout d'abord nous proposons d'exclure certaines espèces de Bursidae, en particulier les plus anciennes Hanaibursa aquilana (Parona, 1909) (Aptien) and Bursa saundersi Adegoke, 1977 (Sélandien). Nous excluons aussi la totalité des espèces du genre Olequahia Stewart, 1926 en discutant de l'analogie de leur canal siphonal postérieur avec celui des Bursidae. Ensuite nous révisons le genre Bursa Röding, 1798, genre type de la famille, sur la base d'une phylogénie précédemment publiée remettant en question la monophylie du genre. Nous créons deux nouveaux genres Olssonia n. gen. (espèce type: Bursa chira Olsson, 1930) et Aquitanobursa n. gen. (espèce type: Ranella grateloupi d'Orbigny, 1852) composés d'espèces fossiles. Nous désignons des lectotypes pour Ranella grateloupi d'Orbigny 1852, Ranella morrisi d'Archiac \& Haime, 1853 et Apollon pelouatensis Cossmann \& Peyrot, 1924. En se basant sur la révision du registre fossile, nous proposons également cinq points de calibration fossile pouvant être utilisés pour dater l'arbre phylogénétique moléculaire de la famille.
\end{abstract}

\section{INTRODUCTION}

The importance of phylogenetic reconstruction no longer needs to be proven and the advances in molecular phylogeny have provided new possibilities for molluscan systematics, renowned for the difficulty of defining primary homologies based on shell characters (Giribet 2015). However, the use of fossils, for which only the shells are available, is unavoidable in modern evolutionary biology because they are the favoured means of calibration for dating molecular phylogenies. A time-tree goes beyond patterns, it gives information regarding tempo of evolution, and allows testing specific hypotheses (e.g., biogeography, diversification rate, etc.). For these reasons time-trees have become used commonly in systematics (Donoghue \& Benton 2007). In the vast majority of cases researchers have used fossils to calibrate molecular trees, providing information to constrain nodes (Donoghue \& Benton 2007). To do so most of them assume that the taxonomy reflects the correct phylogenetic position of the fossils, something that is difficult to justify. Furthermore, it may lead to under-estimation of uncertainty in the resulting node ages if conducted without proper homology hypotheses or phylogenetic assessment (Sterli et al. 2013). Lastly, a wrong node attribution could lead to huge distortions of divergence time (Douzery et al. 2006). Therefore, a review of the fossil record of the considered clade should be done before any analysis.

Parham et al. (2012) discussed a set of data required to justify a fossil calibration. They are: 1) a museum numbers for the specimen(s) that demonstrate all the relevant characters and provenance data; 2) an apomorphy-based diagnosis of the specimen(s); 3) an explicit statement on the reconciliation of morphological and molecular data; 4) the locality and stratigraphic level(s) from which the calibrating fossil(s) was/were collected; and 5) a reference to a published radioisotopic age and/or numeric timescale and details of numeric age selection of the specimen(s). From all these criteria, the most difficult to satisfy when selecting fossils to calibrate a molluscan phylogeny is the third one, due to the homology issues cited above.

In this paper we review the fossil record of the Bursidae Thiele, 1925. This tonnoidean family is currently under systematic revision by the authors, who will produce a molecular phylogeny. In order to do it a re-evaluation of calibration points is required.

Bursidae are a moderately diverse group with 59 living species (Worms 2018). Recent bursids have a tropical and sub-tropical distribution with a southernmost record in eastern South Africa (Sanders et al. 2017), northern New Zealand (Spencer et al. 2016) and Walters shoal (Expeditions Muséum 2018). The northernmost record (Bursa scrobilator (Linnaeus, 1758)) is from Nice, southern France and Savona, north-western Italy (Landau et al. 2004). They are intertidal to subtidal species, most often associated with hard substrates such as rocks, coral or sponges, where they can be locally abundant. They are active predators, feeding on polychaetes, sipunculids and echinoderms (Houbrick \& Fretter 1969; Taylor 1978).

Bursidae are readily recognizable by their well-defined posterior exhalant siphon (anal notch) at the top of the outer lip, attached to the suture and by their thick, coarsely sculptured shells with knobs, warts, tubercles and nodules, hence their vernacular name: frog shells. Their size range is great; the smallest species, Bursa lucaensis (Parth, 1991) never exceeds $23 \mathrm{~mm}$ in height whereas Tutufa bardeyi (Jousseaume, 1881), with a height up to $450 \mathrm{~mm}$ and a width up to 300 $\mathrm{mm}$, has one of the largest and most capacious shell of all gastropods (Beu 1998). Most bursids range in size between 40 and $60 \mathrm{~mm}$.

As inferred from their protoconch, they are assumed to have a long to extremely long larval stage granting, for some of them, trans-oceanic dispersal capabilities. However, Sand- 


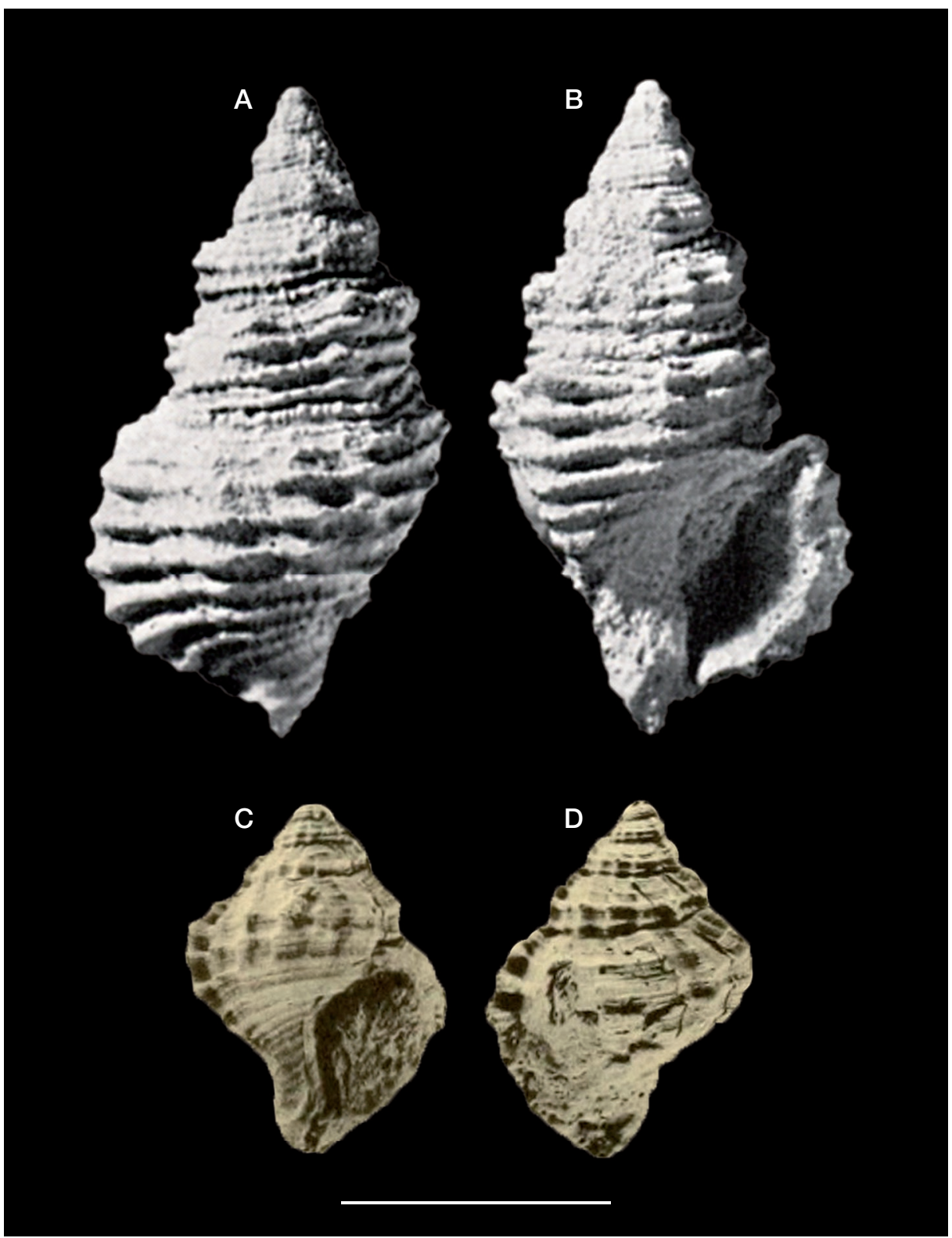

FIG. 1. - Taxa excluded from Bursidae: A, B, Hanaibursa aquilana (Parona, 1909) UMUT MM15655, Hiraiga Formation (Aptian of Japan), reproduced from Kase (1984: pl. 28, fig. 16a); A, dorsal view; B, ventral view; C, D, Bursa saundersi Adegoke, 1977, UIMG 394, holotype, Ewekoro Formation (Selandian of Nigeria), reproduced from Adegoke (1977: pl. 31, figs 27, 28); C, ventral view; D, dorsal view. Scale bar: $2 \mathrm{~cm}$.

ers et al. (2017) showed that such capabilities were greatly overestimated for one of the most widespread species of Bursidae, Bursa granularis (Röding, 1798).

The early evolution of the Bursidae remains shrouded in mystery. Pre-Eocene species described as Bursidae (Kase 1984; Adegoke 1977) have been ascribed to the family with reservation in the literature and will be discussed here. The earliest seemingly undisputed species of Bursidae are known from the American Eocene (Beu 1988). They are represented by the genus Olequahia Stewart, 1926 from the Upper Eocene (Bartonian) of Washington to California, USA and by two Peruvian species attributed by Beu (1988) to the genus Marsupina Dall, 1904, from the Bartonian of Talara Formation and Priabonian of Chira formation. Thereafter, no bursid is recorded until the Rupelian (Stampian) of the Aquitaine Basin (Southwestern France) (P. Lozouet pers. comm.). During the middle Miocene and throughout the Pliocene, the genus Aspa H. Adams \& A. Adams, 1853 became one of the most abundant gastropods in suitable shallow offshore facies of the Aquitaine Basin, Guadalquivir Basin, Western Tethys (Turin Hills) and Paratethys (Landau et al. 2004, 2009, 2011).

This paper aims to review the fossil record of Bursidae, discussing the exclusion of several species from the family. We will provide a morphological description, i.e., an apomorphy-based diagnosis sensu Parham et al. (2012), for all known extinct genera. In addition, we will list and discuss all the necessary information regarding their use as calibration points in phylogenies. Two new genera are described. 


\section{SHELL DESCRIPTION}

Shells are described here using the methods of Sanders et al. (2017) adapted from Merle $(2001,2005)$ for primary homology definition. Primary cords (P) are spiral ornamentations present from the first teleoconch whorl. Secondary cords $(S)$ are spiral ornamentations appearing later during shell ontogeny. The shoulder cord is designated as P1. Cords of the convex part of the whorl are added from adapical to abapical (P2 to P8). The primary cord of the sutural ramp is designated IP and the secondary cord IS. Secondary cords on the convex part of the whorl are designated S1 to S8. Cords of the anterior siphonal canal were not considered.

\section{ABBREVIATIONS}

Specimen repositories

MNHN-IM Muséum national d'Histoire naturelle, collection de malacologie, Paris;

MNHN.F Muséum national d'Histoire naturelle, collection de paléontologie, Paris;

NHMW Naturhistorisches Museum Wien, Vienna;

NMB Naturhistorisches Museum, Basel;

PRI Paleontological Research Institution, Ithaca, New York;

RGM Fossil collections of Netherlands Nationaal Museum van Natuurlijke Historie, Leiden (formerly Rijksmuseum van Geologie en Mineralogie);

UCMP University of California (Museum of Paleontology), Berkeley;

UF Florida Museum of Natural History, University of Florida, Gainesville;

UIMG University of Ife Museum of Geology, Nigeria;

UMUT University Museum, the University of Tokyo, Tokyo;

USNM United States National Museum of Natural History, Washington D.C.;

TU Tulane University, New Orleans.

\section{Shell characters}

AN anal notch;

$\mathrm{H}$ height;

P primary cord;

P1 shoulder cord;

P2-8 primary cords of the convex part of the whorl;

S secondary cord;

S1-8 secondary cords of the convex part of the whorl;

SC siphonal canal;

W width.

\section{EXCLUSION OF SPECIES FORMERLY INCLUDED IN BURSIDAE}

The attribution of the Aptian (Hijochi and Hiraiga formations, Japan) species Hanaibursa aquilana (Parona, 1909) (Fig. 1A, B) to Bursidae by Kase (1984: fig. 16a, b) is most surprising considering that it bears few, if any, bursid characters. When published it was considered to be the oldest known bursid species. The relatively high-spired shell of $H$. aquilana with weak varix-like ridges every $90^{\circ}$ shows greater similarity to batillariid gastropods such as Pyrazopsis Hacobjan, 1972, than with Tonnoidea. Furthermore, the posterior siphonal canal is not homologous to that of bursids, as it appears to be an adaxially extending fold within the outer lip. Riedel (1995) was the first to notice this resemblance with cerithoideans; we agree with him on this superfamily position.

Bursa saundersi Adegoke, 1977 (Fig. 1C, D) was described by Adegoke (1977: 209, pl. 31, figs 27-28) and recognized by Beu $(1998,2010)$ as a possible Paleocene bursid. With aligned prominent varices and coarse spiral sculpture, the small specimen from the Ewekoro Formation (Selandian of Nigeria) looks a lot like a frog shell. Nevertheless, it lacks the posterior siphonal canal, the key character used to discriminate Bursidae from Ranellidae and Cymatiidae. For this reason, we conclude that this species does not belong to crown-Bursidae; Strong et al.(2018) suggested that this species possibly belongs in a new family along with Halgyrineum louisae (Lewis, 1974) and "Ranella" neuvillei Cossmann \& Peyrot, 1924 (both currently included tentatively in Cymatiidae, following the phylogeny of Strong et al. 2018).

According to Beu $(1988,2010)$, there is only one longextinct genus within the family Bursidae: Olequahia Stewart, 1926, with five accepted species (Olequahia domenginica (Vokes, 1939), O. lincolnensis (Weaver, 1916), O. lorenzana (Wagner \& Schilling, 1923), O. schencki Durham, 1944, and O. washingtoniana (Weaver, 1912)). Specimens presented here (Fig. 2) challenge this classification.

The type species of the genus, Olequahia washingtoniana (Fig. 2C-H), possesses an ornamentation pattern constituted mostly of spiral cords, the primary cords more prominent than the secondary ones. Nodules are consistently present on the shoulder. Two rows of nodules are present adapically; however, they fade into cords after half a whorl, an unusual feature among Bursidae, but found in Galeodea Link, 1807 (Cassidae). The low spire and inflated last whorl of $O$. washingtoniana are more reminiscent of shells of Cassidae or Tonnidae than of Ranellidae, Cymatiidae or Bursidae. In this species, varices are only present on the first whorl and as a terminal varix. According to Beu (1988), pre-terminal varices are entirely lost in Oligocene species.

Varices are an important character because every single species of Bursidae possesses them even though they may be reduced in some cases (e.g. in Aspa marginata (Gmelin, 1791)). According to Strong et al. (2018) tonnoidean varices are most probably a plesiomorphic character (with an apomorphic loss due to varix dissolution during ontogeny in the clade Tonnidae + Cassidae). This lack of a varix on every whorl suggests that Olequahia may not be correctly referred to Bursidae.

However, Olequabia washingtoniana has a well-defined posterior siphonal canal resembling that of Bursidae. This siphonal canal is unusually large, similar to that in species of Crossata Jousseaume, 1881; this led some authors (Beu 1988; Albi 2002) to consider Olequahia as possibly "ancestral" to Crossata. We consider the posterior siphonal canal of Olequahia to be structurally different from that of Crossata (or any other Bursidae). The siphonal canal of Olequahia is formed by two rather large tubercules, one on the parietal part of the columella and one on the inner part of the outer 


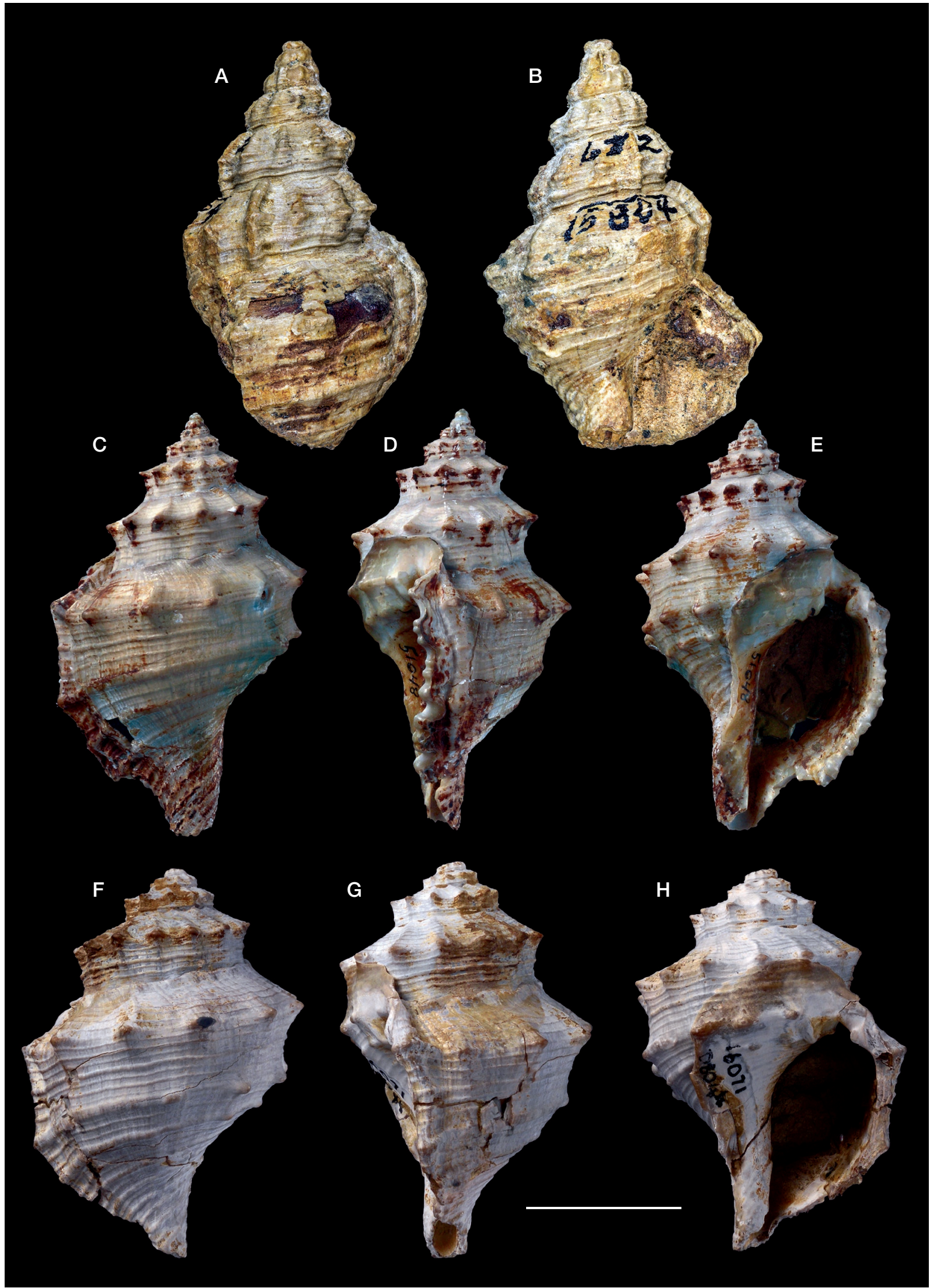

FIG. 2. - Taxa excluded from Bursidae. Olequahia Stewart, 1926 species: A, B, Olequahia domenginica (Vokes, 1939): UCMP 15804, syntype of Ranella domenginica, Tejon formation (Bartonian), California, United States; A, dorsal view; B, ventral view; C-H, Olequahia washingtoniana (Weaver, 1912): UCMP 16071 (loc. ID D8044), in dorsal (C, F), left lateral (D, G) and ventral views (E, H), all from Cowlitz Formation (Priabonian), Cowlitz River, Washington, United States. Scale bar: $2 \mathrm{~cm}$. 
lip. Columellar tubercules may occur in bursids (e.g. Bursa latitudo Garrard, 1961; see Fig. 3E[black arrow]), although never as large as in $O$. washingtoniana and, to our knowledge, there is no species of Bursidae with a single large tubercle or denticle inside the outer lip (in bursids there is either no denticle, or denticles are present throughout the outer lip). However, this feature occurs in several cassid species in the genus Galeodea (e.g., Galeodea hoaraui Drivas \& Jay, 1989). In the light of our reinterpretation of these characters, we consider that $O$. washingtoniana is not a species of Bursidae.

Though many clues may indicate that Olequahia washingtoniana belongs in Galeodea, some characters do not point in that direction. The high-spired protoconch of this species (Beu 1988: fig. 1F) is quite different from the short, wide protoconch of one whorl in Galeodea; the columella is curved in Galeodea and straight in Olequahia; and finally, the wavy, frilly outer lip extension of $O$. washingtoniana is quite unique among tonnoideans. The position of $O$. washingtoniana in Galeodea, as a genus of Cassidae or even as a new family of Tonnoidea requires further attention but is beyond the scope of this paper.

Olequahia domenginica (Fig. 2A, B) is the oldest known species referred to the genus. The figured syntype has prominent varices every $200^{\circ}$ or so over the entire teleoconch and is taller and narrower than its congeners. However, the general ornamentation resembles that of $O$. washingtoniana. Furthermore, the shell has no anal notch, casting doubts on its kinship with Bursidae. This shell is more reminiscent of a cymatiid such as Monoplex Perry, 1810. It is quite possible that it is more closely related to Monoplex than to O. washingtoniana. Either way, it is not a species of Bursidae. The other syntype of O. domenginica (UCNP 15803, not figured) is slightly larger than the illustrated specimen, but otherwise quite similar. However, the ventral side is not preserved in this specimen.

\section{TACKLING BURSA IN THE FOSSIL RECORD}

As currently understood, Bursa Röding, 1798 is very morphologically variable, so variable in fact that Beu (1998: 143) gave the broad generic description that "Bursa is a large genus containing species with short to tall spires, weak to coarse sculpture, heavy and thick to light, thin shells, with varices variable in position [...] and with or without a red colour area on the parietal lip". One conclusion may be that Bursa is a "trash" genus, and exists only to classify species that do not fit anywhere else (this status was confirmed by Castelin et al. 2012 [Fig. 4] and Strong et al. 2018). Being paraphyletic (or polyphyletic), such genera are an impediment for every systematist aiming to describe biodiversity in its historical dimension (Faurby et al. 2016).

To our knowledge there are 14 recognized extinct species of Bursidae, two-thirds of them referred to Bursa (Bursa amphitrites Maury, 1917, B. chipolana Schmelz, 1997, Ranella grateloupi d'Orbigny, 1852, Apollon inaequicrenatus Cossmann \& Peyrot, 1924, B. sangirana Beu, 2005, R. tuberosa Grateloup, 1833, $B$. victrix Dall, 1916, $R$. morrisi d'Archiac \& Haime, 1853 and B. landaui Harzhauser, 2009) and the rest to Marsupina Dall, 1904 (Bursa chira Olsson, 1930, Bursa (Marsupina) freya Olsson, 1932, Bursa chira var. yasila Olsson, 1930, Marsupina judensis Beu, 2010, and Gyrineum strongi Jordan, 1936).

Following Beu's $(1988,2010)$ opinion we consider Marsupina freya, $M$. judensis and $M$. strongi to be correctly attributed to the extant genus Marsupina.

As we want Bursa to be monophyletic, based on the phylogeny of Castelin et al. (2012) and considering the position of the type species of the genus (B. bufonia (Gmelin, 1791)), we end up with a narrower definition of Bursa; it contains only $B$. bufonia and B. lamarckii (Deshayes, 1853), to which we can add B. luteostoma (Pease, 1861), B. rosa (Perry, 1811) and B. tuberosissima (Reeve, 1844), on the basis of their tubular and elongated posterior siphonal canal.

None of the fossil species mentioned above are closely similar to Bursa bufonia and none of them are type species of a previously published name that could be resurrected. So we are left with two options: either erect new genera (as few as possible) or propose phylogenetic hypotheses linking fossils with extant species (preferably type species).

Bursa sangirana Beu, 2005 (Fig. 5E), from the late Pliocene Kalibeng layers (Sangiran, central Java), has a low spire with a warty ornamentation. Its posterior siphonal canal is short; it is very reminiscent of Bursa rhodostoma (G. B. Sowerby II, 1835) (Fig. 3F) and is probably closely related to it. Both species may be included in the separate genus Lampadopsis Jousseaume, 1881 for which $B$. rhodostoma is the type species. The resurrection of this genus was suggested recently by Strong et al. (2018).

Bursa landaui Harzhauser, 2009 (Fig. 4C, D): this slender shell is only known by two external molds from the Aquitanian of Ras Tipuli, Lindi Bay, Tanzania. It has a very fine granulose ornamentation and a weakly expressed shoulder, slightly reminiscent of Bursa granularis (Röding, 1798) (Fig. 3G) and similar to Bursa condita (Fig. 3A). This may be an indication of the close relationship of the three species, for which there are two or possibly three available generic names: Colubrellina Fischer, 1884 and Dulcerana Oyama, 1964. Bufonariella Thiele, 1929 is possibly another available name considering the close resemblance of its type species, Bursa scrobilator (Linnaeus, 1758), to B. granularis.

Bursa victrix Dall, 1916: this species is only known from a poorly preserved external mold (USNM 166728) from the late Oligocene of Mascot Point, Flint River, Georgia, United States. The almost evenly inflated whorl profile, with a slightly protruding shoulder angle formed by a row of rounded nodules at approximately the upper third of the whorl height on the spire, the numerous lower rows of nodules extending down over the anterior canal, and the deeply buttressed abapertural face of the varix on the ultimate whorl are all characters in common with Bursa corrugata (Perry, 1811) (Fig. 3D). We follow Beu's (2010) opinion, keeping it as a species separate from $B$. corrugata pending the discovery of better-preserved specimens.

Among the remaining extinct bursid species, two are strikingly similar: Marsupina chira (Olsson, 1930) and M. yasila 


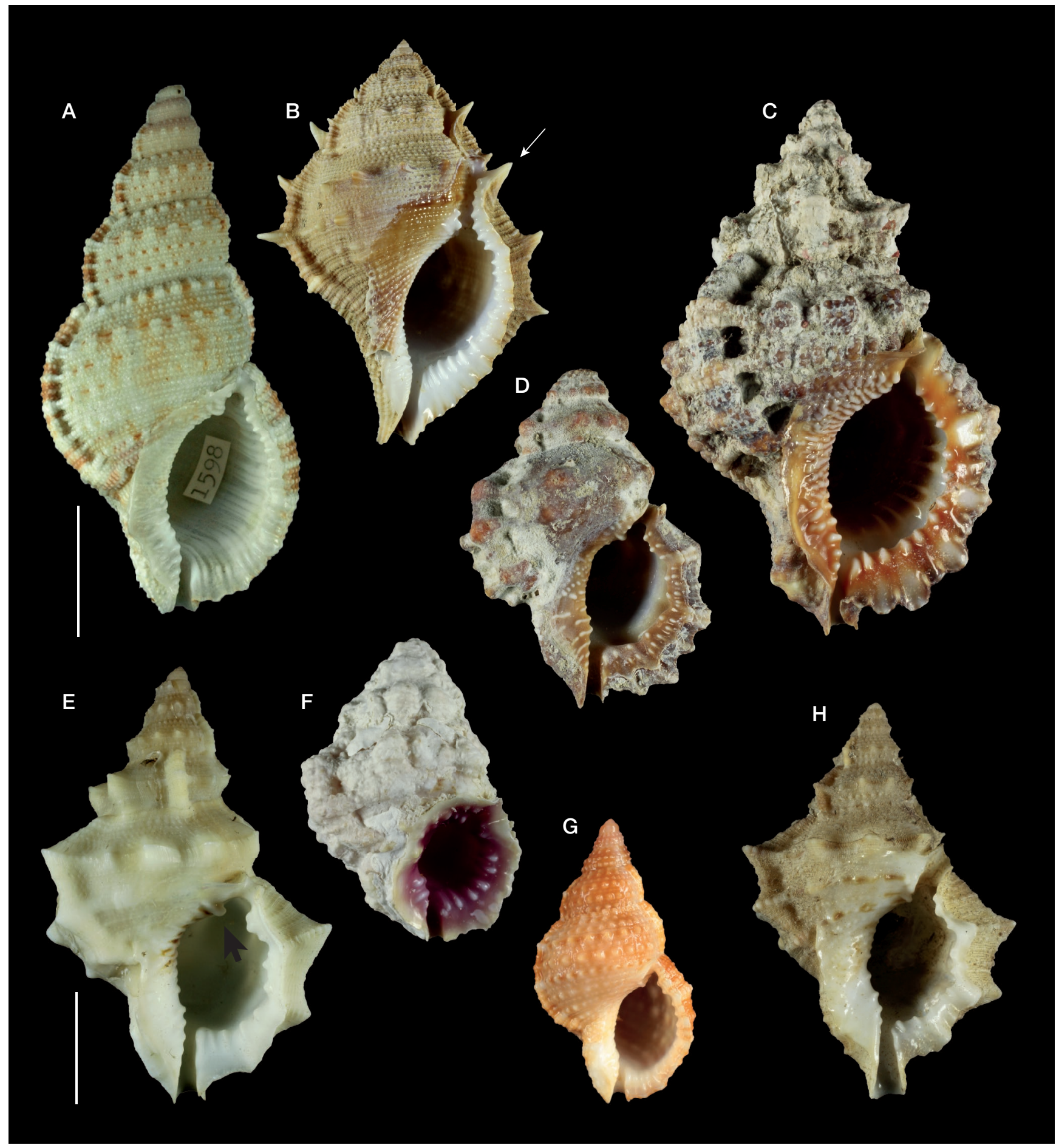

FIG. 3. - Recent Bursidae: A, IM-2008-5350, Bursa condita (Gmelin,1791), « Nouvelle Calédonie ", Jousseaume coll.; B, IM-2007-43072, Bufonaria perelegans Beu, 1987, Santo Marine Biodiversity Survey 2006, Vanuatu; C, IM-2009-11906, Bursa corrugata (Perry, 1811), Dakar'09, Senegal; D, IM-2007-43063, Tutufa rubeta (Linnaeus, 1758), Santo Marine Biodiversity Survey 2006, Vanuatu; E, IM-2007-40338, Bursa latitudo Garrard, 1961, Exploration de la Biodiversité et Isolement en mer du Corail, Nouvelle Calédonie; F, IM-2009-5150, Lampadopsis rhodostoma (G.B. Sowerby II, 1835), MAINBAZA, Mozambique channel; G, IM-2009-5148, Bursa granularis (Röding, 1798), juvenile, MAINBAZA, Mozambique channel; H, IM-2009-11653, Bursa quirihorai Beu, 1987, Exploration de la Biodiversité et Isolement en mer du Corail, New Caledonia. All are ventral views. Scale bars: A-D, $2 \mathrm{~cm}$; E-H, $1 \mathrm{~cm}$.

(Olsson, 1930), for which we propose a new genus, Olssonia n. gen.

In the same fashion, Bursa amphitrites Maury, 1917, B. grateloupi (d'Orbigny, 1842), B. inaequicrenata (Coss- mann \& Peyrot, 1923), B. tuberosa (Grateloup, 1833), Bursa chipolana Schmelz, 1997, and Ranella morrisi d'Archiac \& Haime, 1853 are here attributed to a new genus: Aquitanobursa $\mathrm{n}$. gen. These new genera are described below. 


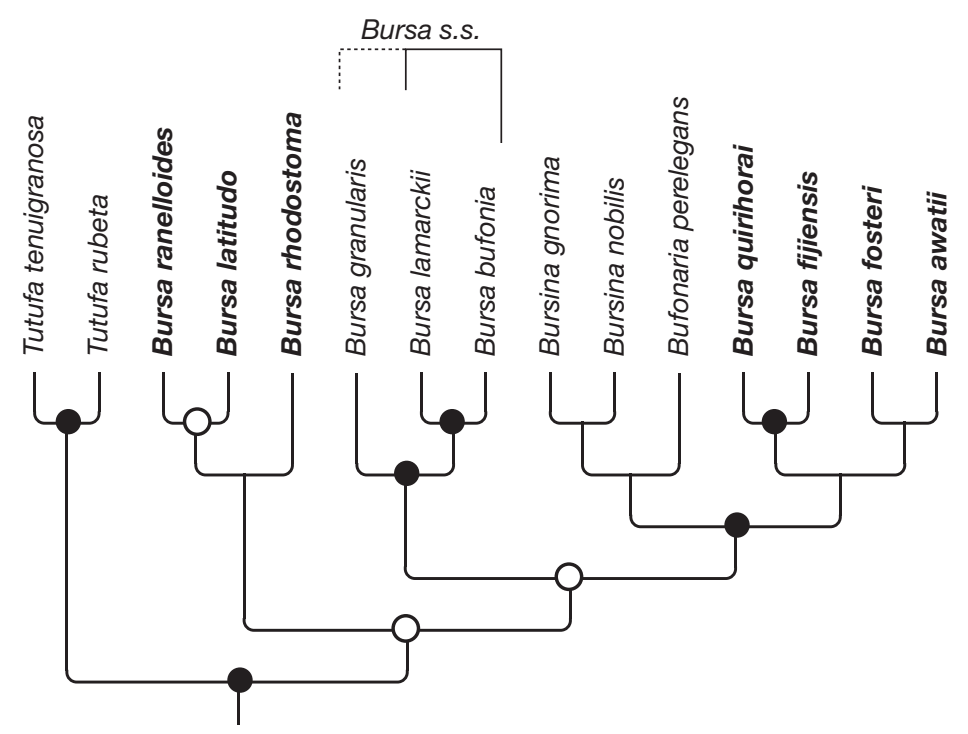

FIG. 4. - Phylogeny of the Bursidae. Topology based on the multigene Bayesian analysis of Castelin et al. (2012); black dots (•) represent well supported nodes (posterior probabilities over 0.98 ) and white dots $(O)$ represent moderately supported nodes (PP over 0.90). Bursa species in bold type are taxa that make the genus polyphyletic. Bracket on top indicates the phylogenetic extent of the genus Bursa if we consider the tubular posterior siphonal canal to be one of its synapomorphies, dotted bracket indicates the maximum extent of the genus considering the topology.

\section{ON THE GENUS ASPA}

Aspa is the most abundant fossil bursid. This is possibly due to its extremely thick shell. Some authors (Malatesta 1974; Baluk 1995; Solsona 1998) suggested that Aspa was monospecific with the extant species Aspa marginata ranging from the earliest Miocene (Aquitanian of Landes or Rupelian, France [Beu 2010]) to the Recent. However, early specimens possess a higher spire, coarser sculpture, a row of nodules at P1 persisting onto the last whorl and an obsolescent lower row of nodules, and larger nodules inside the outer lip than in Recent specimens of $A$. marginata. This led Landau et al. (2004, 2009) and Beu (2010) to the conclusion that the earliest specimens of Aspa belong to another species, for which they considered the valid name to be Aspa subgranulata (d'Orbigny, 1852) (Fig. 6). The exact upper range of $A$. subgranulata and the exact lower range of $A$. marginata are not well defined due to the use of the name $A$. depressa (Grateloup, 1833) for either of the two species. This species was originally considered as a "transition" species by Cossmann \& Peyrot (1924), ranging from the Langhian to the Messinian. This species is currently considered a junior synonym of $A$. marginata (Landau et al. 2004, 2009; Beu 2010). Further quantitative studies should be conducted to determine the exact ranges of the two (or three) species.

\section{SYSTEMATICS}

Phylum MOLLUSCA Cuvier, 1795

Class GASTROPODA Cuvier, 1797

Superfamily TONNOIDEA Suter, 1913 (1825)

(Conserved under ICZN Article 40b)
Family BursidaE Thiele, 1925

Genus Olssonia n. gen. urn:Isid:zoobank.org:act:9BB6F0C9-71ED-4F96-BAE8-3BA325B57714

TYPE SPECIES. - Bursa chira Olsson, 1930.

DeRIVATIO NOMINIS. - Dedicated to the American palaeontologist A. A. Olsson.

SpeCies InCluded. - Olssonia chira (Olsson, 1930) n. comb., O. yasila (Olsson, 1930) n. comb.

Distribution. - Olssonia n. gen. is a genus restricted to the Eocene to early Miocene of Peru.

DiAgNOSIs. - Shell biconic, dorsoventrally compressed, shortspired, with 7 primary cords on the convex part of the whorl, all but $\mathrm{P} 1$ evenly reduced in variceal and intervariceal intervals of each whorl (P1 hardly more expressed than other cords); posterior siphonal canal short; varices strictly aligned; prominent columellar callus.

Comparisons. - Olssonia n. gen. resembles Marsupina but possesses a lesser number of primary cords on the convex part of the whorl (7 in Olssonia n. gen., 8 in Marsupina). It resembles Aspa but has a much more prominent columellar callus, it is much more granulose, and it has a more sharply defined shoulder and a wider spire angle. Olssonia n. gen. resemble Bufonaria (Fig. 3B), with the same straight anterior siphonal canal, but lacks a spine or blade on the posterior siphonal canal (Fig. 3B; white arrow).

\section{REMARKS}

The representatives of this genus are the oldest confirmed Bursidae; as such they can be used to calibrate the node Bursidae. 

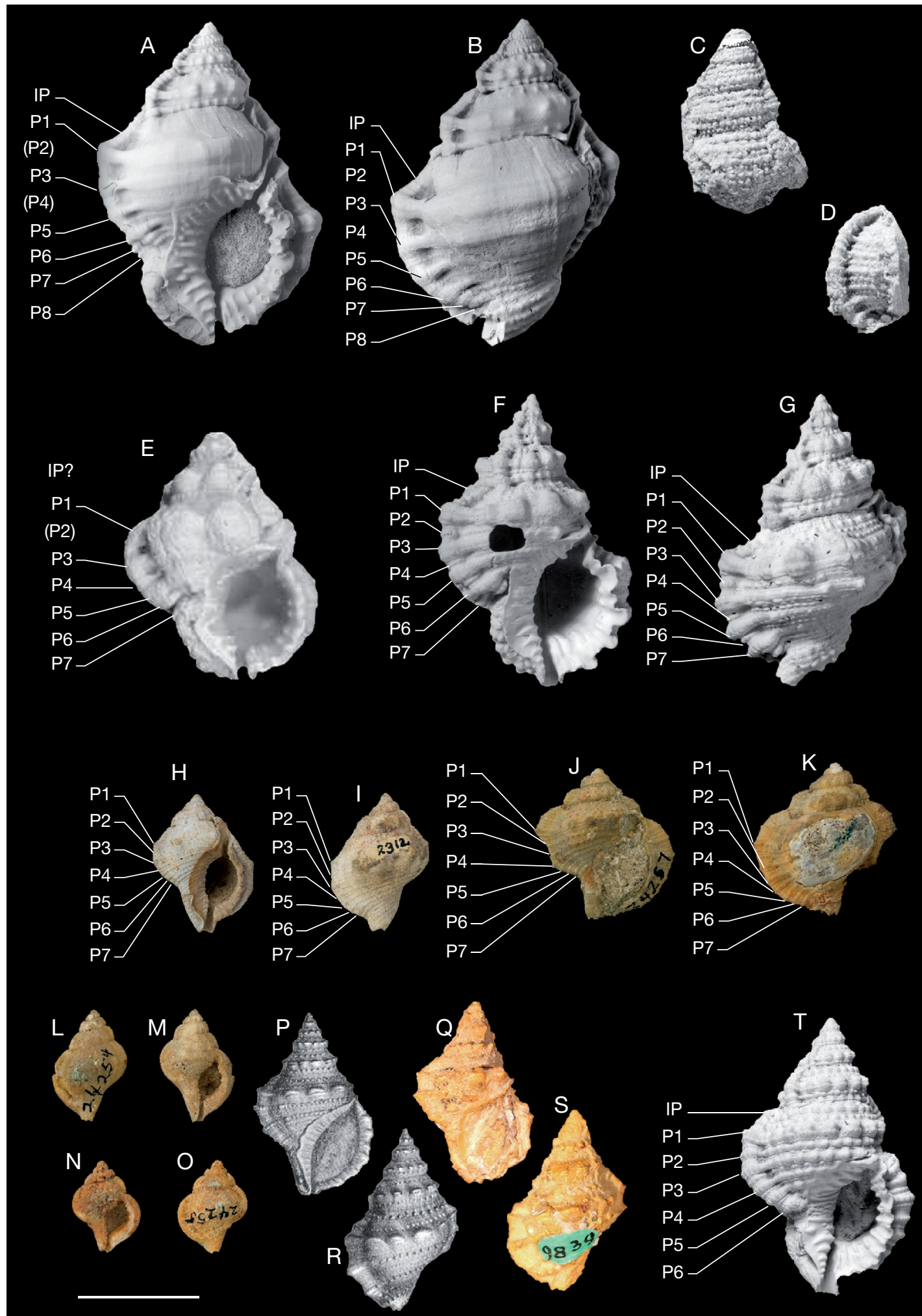

FIG. 5. - Extinct Bursidae species: A, B, Marsupina judensis Beu, 2010; NMB H 18308, holotype, late Miocene, Punta Judas, Pacific Costa Rica, reproduced from Beu (2010); C, D, "Bursa" landaui Harzhauser, 2009, NHMW 2007z0181/0029 (C) holotype and NHMW 2007z0181/0030 (D), both from the Aquitanian of Ras Tipuli, Lindi Bay, Tanzania, reproduced from Harzhauser (2009); E, Lampadopsis sangirana (Beu, 2005), RGM 456 230, holotype, late Pliocene of Kalibeng layers, Sangiran, central Java, reproduced from Beu (2005); F, G, Aquitanobursa chipolana (Schmelz, 1997) n. comb., USNM 647108, paratype, specimen illustrated by Vokes (1973: text-figs 2a, b), coral reef facies of Chipola Formation (late Early Miocene), loc. TU547, reproduced from Beu (2010); H, I, Marsupina freya (Olsson, 1932), PRI 2312, holotype, "Zorritos Miocene," divide between Quebrada Conchudo Bravo and Quebrada Seca, Mancora, Peru; J, K, Olssonia chira (Olsson, 1930) n. comb., PRI 24257, holotype, Late Eocene/Oligocene of Chira Formation, Quercotilla, Peru; L-O, Olssonia yasila (Olsson, 1930) n. comb., PRI 24254 (L, M) and PRI 24255 (N, O), Middle Eocene Talara Formation, Yasila, Peru; P-S, Aquitanobursa morrisi (d'Archiac \& Haime, 1853) n. comb., original representation of one of the syntypes by d'Archiac \& Haime (1853) (P, R) and (NHMUK PI TG 27045) lectotype, from "Calcaire grossier jaune de la chaîne d'Hala" (Aquitanian?) Pakistan; T, Aquitanobursa amphitrites (Maury, 1917) n. comb., PRI 28763, holotype, Cercado Fm (Late Miocene), Maury's bluff 3, Cercado de Mao, Dominican Republic, reproduced from Beu (2010). Scale bar: 2 cm. 


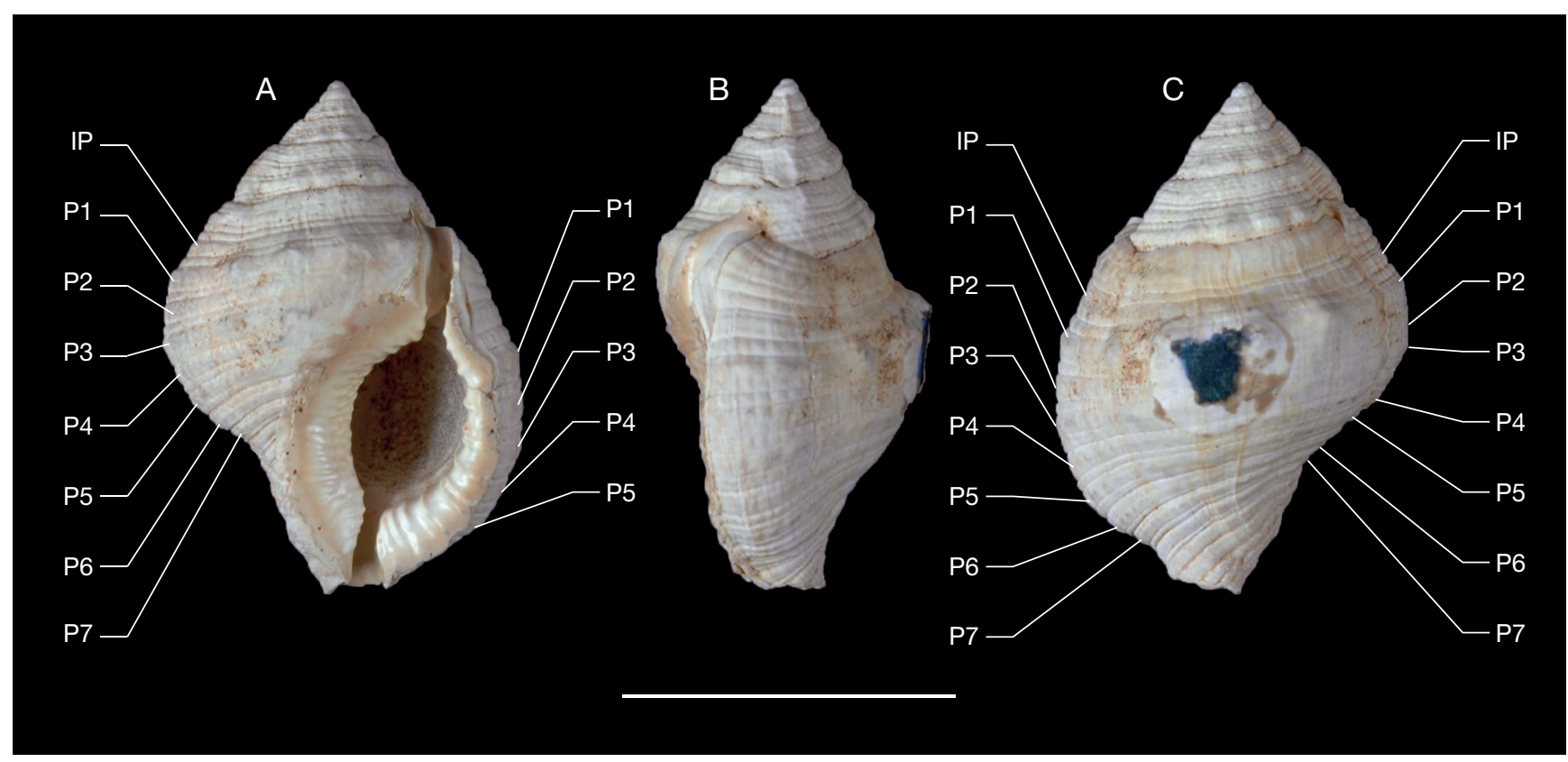

FIG. 6. - Aspa subgranulata (d'Orbigny, 1852). MNHN.F.A70283 (Brongniart coll.), ventral (A), lateral left (B) and dorsal (C) views, Miocene of Le Peloua, Landes, France. Scale bar: $2 \mathrm{~cm}$

Olssonia chira (Olsson, 1930) n. comb.

(Fig. 5L, M)

Bursa chira Olsson, 1930: 62, pl. 10, figs 5-7,13.

Marsupina chira-Beu 1988: 71; 2010: 72.

TYPE MATERIAL. - Holotype (PRI 24257), one paratype (PRI 24263).

TYPE LOCALITY. - Late Eocene/Early Oligocene of Chira Formation, Quercotilla, Peru .

GEOGRAPHIC AND STRATIGRAPHIC OCCURRENCE. - Olssonia chira n. comb. seems to occur only on the Late Eocene/Early Oligocene of Peru.

Olssonia yasila (Olsson, 1930) n. comb. (Fig. 5N, O)

Bursa chira var. yasila Olsson, 1930: 63, pl. 10, figs 3, 4.

Marsupina yasila - Beu 1988: 71.

Type LOCALITY. — Middle Eocene (Bartonian) Talara Formation, Yasila, Peru

TYPE MATERIAL. - Holotype (PRI 24254), with two paratypes (PRI 24255 and PRI 24262).

GEOGRAPHIC AND STRATIGRAPHIC OCCURRENCE. - Known only from the Bartonian of Peru.

Genus Aquitanobursa n. gen.

urn:Isid:zoobank.org:act:69CEE556-A552-4FB2-AE6A-2FCB4374C21D
TYPe SPECIES. - Ranella grateloupi d'Orbigny, 1852.

Derivatio NOMINIS. - Derived from Aquitaine (Aquitania in Latin), the region where most of the species of the genus occur.

SPECIES INCLUDED. - Aquitanobursa grateloupi (d'Orbigny, 1852) n. comb., Aq. amphitrites (Maury, 1917), n. comb., Aq. inaequicrenata (Cossmann \& Peyrot, 1924) n. comb., Aq. morrisi (d'Archiac \& Haimes, 1853) n. comb., Aq. tuberosa (Grateloup, 1833) n. comb.

DiAGNOSIs. - Shell thick, moderately short-spired, varices slightly displaced, 6 primary cords on the convex part of the whorl, variceal and intervariceal P2 very reduced, axial ridges on the first whorl, parietal callus prominent. Posterior siphonal canal short, well-defined; outer lip with weak projection.

COMPARISON. - With their deeply marked and angular varices and strongly expressed shoulder, Aquitanobursa n. gen. species resemble some deep-sea species of the Bursa s.l. genus such as Bursa quirihorai Beu, 1987 (Fig. 3H); however, Aquitanobursa n. gen. species are much strongly built, with a thicker shell.

Atavistic features displayed by deep-sea gastropods are a well-known phenomenon, described recently for Muricidae by Merle (2012). The phylogenetic relationships of Aquitanobursa n. gen. with other Bursidae remain unclear; this genus is possibly a sister group to all Recent Bursidae, but that in unlikely considering that it occurs at the same time as Aspa marginata and Bursa corrugata. A fair assumption would be that it is the sister group to all bursids except Aspa and B. corrugata, but that would need a phylogenetic analysis for confirmation.

Aquitanobursa grateloupi (d'Orbigny, 1852) n. comb. (Fig. 7A)

Ranella gratteloupi [sic] d'Orbigny, 1852: 76.

Ranella leucostoma - Grateloup 1833: 91, pl VI (not Lamarck, 1822). Ranella semigranosa-Grateloup 1845: pl. XXIX, fig. 6 (not Lamarck, 1822). 

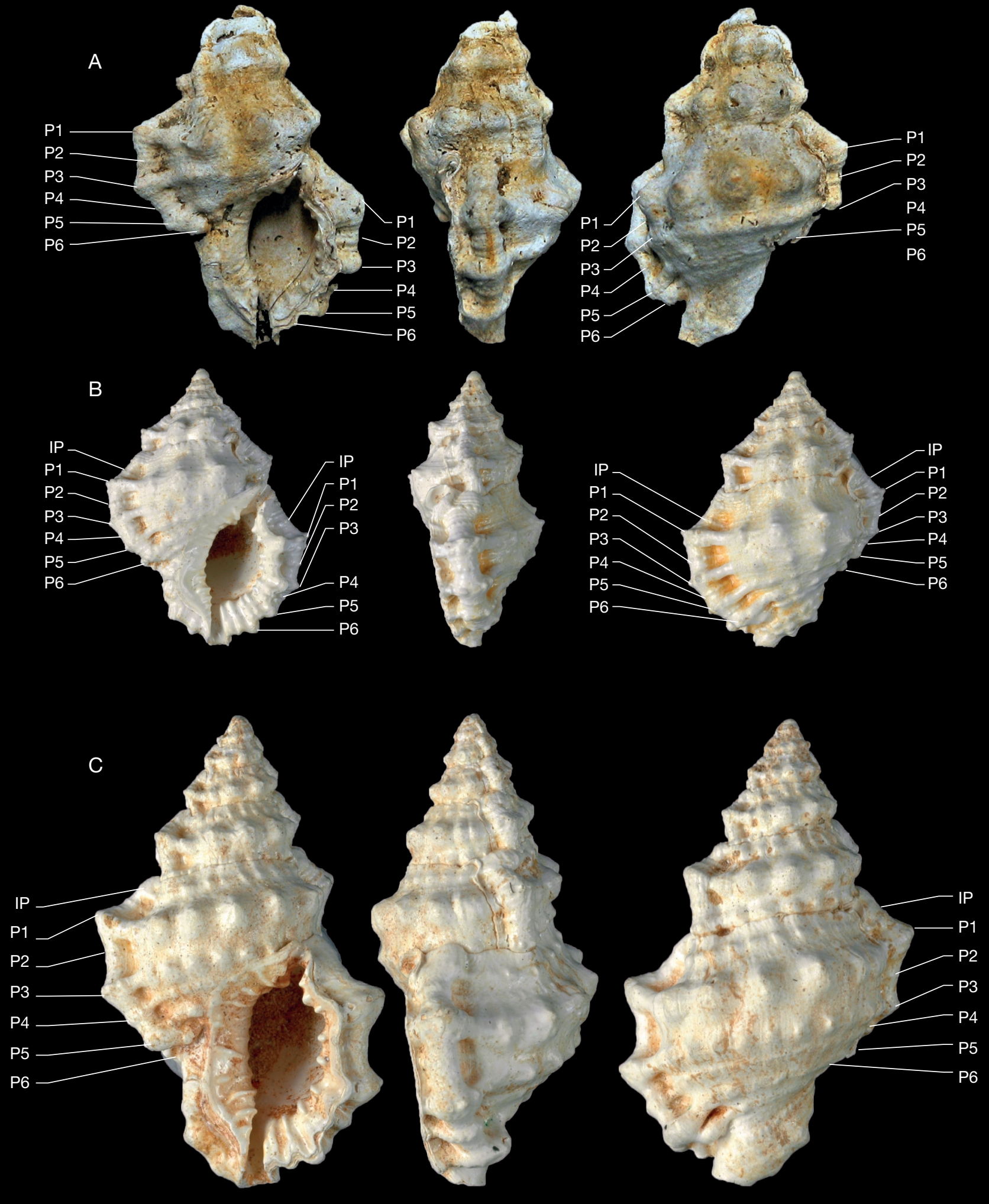

FIG. 7. - Aquitanobursa n. gen. of Aquitaine Basin: A, Aquitanobursa grateloupi (d'Orbigny, 1852) n. comb., MNHN.F.A27211, lectotype from the Aquitanian of Saint-Paul-les-Dax, France; B, Aquitanobursa inaequicrenata (Cossmann \& Peyrot, 1924) n. comb., MNHN.F.A70284, Burdigalian of le Peloua, France; Faullummel coll.; C, Aquitanobursa tuberosa (Grateloup, 1833) n. comb., MNHN.F.A70285, Burdigalian of le Peloua, Staadt coll. 
Apollon grateloupi-Cossmann \& Peyrot 1924: 305, pl. XV, figs 42, 43.

TyPe LOCALITY. - Lower Miocene of Aquitaine Basin, Bordeaux and Saint-Paul-lès-Dax, France.

TyPe MATERIAL. - MNHN.F.A27211 (from Saint-Paullès-Dax) is here designated as lectotype. One paralectotype (MNHN.F.B27595).

OTHER MATERIAL EXAMINED. — 13 specimens from Brongniart coll. from le Peloua, Burdigalian.

GEOGRAPHIC AND STRATIGRAPHIC OCCURRENCE. - Bursa grateloupi is only known from the lower Miocene of the Aquitaine Basin.

\section{REMARKS}

Aquitanobursa grateloupi n. comb. was originally written gratteloupi. This name is obviously based on that of J.P.S. de Grateloup, and in accord with ICZN 32.5.1 the correct spelling is Aquitanobursa grateloupi n. comb.

\section{Aquitanobursa amphitrites (Maury, 1917) n. comb.}

(Fig. 5T)

Bursa amphitrites Maury, 1917: 273, pl. 17, fig. 9. - Beu 2010 42, pl. 1, figs $1-4,8$.

Bursa amphitrites - E. Vokes 1973: 100 (in part = Marsupina bufo) (not Maury, 1917).

Bursa (Colubrellina) caelata amphitrites - Aguilar in Seyfried et al. 1985: 64, appendix (not Maury, 1917).

TyPe LOCAlity. - Bluff 3, Cercado de Mao, Dominican Republic; Cercado Formation, late Miocene.

Type Material. - Holotype (PRI 28763).

GEOGRAPHIC AND STRATIGRAPHIC OCCURRENCE. - Occurs from the Late Miocene to Early Pliocene Gurabo Formation (Tortonian to Piacenzian, according to Denniston et al. 2008) in the Dominican Republic and from the early Middle Miocene Buenevara Adentro beds of the Paraguaná Peninsula, Venezuela (Beu 2010).

Aquitanobursa chipolana (Schmelz, 1997) n. comb. (Fig. 5F, G)

Bursa (Bufonariella) chipolana Schmelz, 1997: 105, pl. 1, figs 1a-c; pl. 2, figs 1a-b, 2a-b. - Vokes 1997: 212.

Bursa (Bufonariella) pelouatensis - Vokes 1973: 97, text-fig. 2 (not Cossmann \& Peyrot, 1924).

Bursa chipolana - Beu 2010: 44, pl. 1, figs 5-7, 10.

Type LOCALITY. - Tulane University locality TU546, Chipola Formation (Burdigalian), Tenmile Creek, Florida, United States.

TYPE MATERIAL. - Bursa (Bufonariella) chipolana, holotype (UF 73199), figured paratype (USNM 647108), from TU547, west bank Chipola River $600 \mathrm{~m}$ upstream from Fourmile Creek, Calhoun Co. (specimen figured by Vokes 1973: text-figs 2a-b, refigured in good quality by Beu 2010: pl. 1, figs 6, 7); figured paratype (UF 73200), from TU951, Tenmile Creek, Calhoun Co.; nine further paratypes from localities on or near the Chipola River listed by Schmelz (1997).
GeOgraphic AND STRATIGRAPHIC OCCURRENCE. - Aquitanobursa chipolana n. comb. is recorded only from the Chipola Formation (Burdigalian) on and near the Chipola River, Calhoun Co., Florida, United States.

\section{REMARKS}

Aquitanobursa chipolana n. comb. seems to have a slightly greater number of primary cords than other species referred to Aquitanobursa n. gen. This species possibly belongs in another genus, for which a new name needs to be created.

\section{Aquitanobursa inaequicrenata \\ (Cossmann \& Peyrot, 1924) n. comb.}

(Fig. 7B)

Apollon inaequicrenatus Cossmann \& Peyrot, 1924: 311 pl. 15, figs 44-45.

Bursa (Bufonariella) inaequicrenata - Beu 1981: 258.

Bursa inaequicrenata - Landau et al. 2004: 68; 2009: 76.

TyPE LOCALITY. - Burdigalian of Le Peloua, near Saucats (Gironde), Aquitaine Basin, France.

TYPE MATERIAL. - Apollon inaequicrenatus, holotype (MNHN.FJ06127 Cossmann coll.) from the Burdigalian of Le Peloua and one paratype (MNHN.F.J06128 Cossmann coll.).

OTHER MATERIAL EXAMINED. - Five specimens from Brongniart coll., three from le Peloua, Burdigalian, one from Saint-Paul-lesDax (Cabannes), Burdigalian, one from Saubrigues, Burdigalian; one specimen from Jussieu coll., from Mérignac, Burdigalian; one specimen from Lhomme coll., from Saucats, Aquitanian; all housed in the collection de Paléontologie, MNHN.

GEOGRAPHIC AND STRATIGRAPHIC OCCURRENCE. - Only known from the Atlantic Aquitaine Basin of France (Aquitanian and Burdigalian).

\section{Aquitanobursa morrisi}

(d'Archiac \& Haime, 1853) n. comb. (Fig. 5P-S)

Ranella morrisi d'Archiac \& Haime, 1853: 309, pl. XXX, fig. 1, pl XXXI, fig. 3.

Ranella elegans - Martin 1884: 137 (not G.B. Sowerby 2nd 1836 in G.B. Sowerby $1^{\text {st }} \&$ G.B. Sowerby 2nd $1832-1841$ ).

Apollon morrisi - Harzhauser et al. 2009: 360, pl. 1.

TyPe LOCALITY. - "Calcaire grossier jaune de la chaîne d'Hala”, Pakistan.

TYPE MATERIAL. - Types figured by d'Archiac \& Haime (1853) previously in UK Geological Survey, now in NHMUK. The complete specimen (NHMUK PI TG 27045) is here designated as the lectotype. One paralectotype (NHMUK PI TG 27046).

GeograpHiC AND STRATIGRAPHIC OCCURRENCE. - This species is only known by d'Archiac \& Haime's (1853) specimens for the lower Miocene of Halla Mountain, Sindh, Pakistan. 
Aquitanobursa tuberosa (Grateloup, 1833) n. comb. (Fig. 7C)

Ranella tuberosa Grateloup, 1833: 92, no. 420. - Bellardi 1873: 236, pl. 15, fig. 7.

Ranella subtuberosa d'Orbigny, 1852: 76, no. 1405.

Apollon pelouatensis Cossmann \& Peyrot, 1924: no. 842, pl. 15, figs 38-39, pl. 17, figs 1-2.

Bursa (Bufonariella) pelouatensis-Beu 1981: 258. - Schmelz 1997: 106, pl. 1, fig. 2.

Bursa tuberosa - Lozouet et al. 2001: 45, pl. 19, figs 3a-3b. - Landau et al. $2004: 68$.

Type LOCALITY. - Ranella tuberosa and Apollon pelouatensis both from the Aquitanian of Saint-Paul-Lès-Dax, France.

TYPE MATERIAL. - Ranella tuberosa syntypes in Grateloup coll., University of Bordeaux, Talence, France (not seen); Apollon pelouatensis: the specimen MNHN.F.J06123 is here designated as lectotype. Three paralectotypes (MNHN.F.J06124, J06125, J06126).

OTHER MATERIAL EXAMINED. - Two specimens from Hofstetter coll., from le Peloua, Burdigalian, and one from Saubrigues, Burdigalian; 13 specimens from Brongniart coll., from le Peloua, Burdigalian; 15 specimens from Staadt coll., from le Peloua, Burdigalian; one specimen from Lhomme coll., from le Peloua, Burdigalian; two specimens (MNHN.F.A70577, A70578) from Gaas "Lagouarde", Rupelian; all in the collections de paléontologie, MNHN.

GEOGRAPHIC AND STRATIGRAPHIC OCCURRENCE. - Rupelian to middle Miocene of the Aquitaine basin (France) and Po Valley (Italy).

\section{RECOMMENDATIONS FOR CALIBRATION}

In regard to the systematic considerations, we can provide some recommendations for calibration of the molecular tree of the Bursidae. Numerical dating for this section is provided by the international geological time scale (Gradstein et al. 2012); a complete stratigraphic distribution chart for the Bursidae is shown in Figure 8. First occurrence and last occurrence data are provided in Appendix 1.

Considering that it is the oldest undisputable taxon included in Bursidae and apparently is not closely related to other clades within the family, the genus Olssonia n. gen. seems to be the best candidate for the calibration of the whole Bursidae. The oldest representative of the genus is O. yasila n. comb. from the early Bartonian (Olsson 1932, Beu 1988) for which we propose to use an age of 41.2 Ma. As for all the following node calibrations, we propose to apply a truncated log normal distribution, as it places the highest probability on ages somewhat older than the fossil, diversification being necessarily older than the observed fossil record (Ho \& Phillips 2009).

The genus Aspa does not resemble any other Bursidae closely and, considering its very long stratigraphic history, possibly commencing before the Neogene (Landau et al. 2004), it may very well be a sister group to the rest of the Recent Bursidae. On the other hand, the fossil genus Aquitanobursa n. gen. looks like some Recent species such as B. quirihorai and B. granosa.
If $A s p a$ were to branch at the base of the Bursidae tree, the clade containing every other bursid but excluding Aspa could be calibrated by Aquitanobursa n. gen. The oldest representative of the genus (two specimens MNHN.F.A70577, A70578) is $A$. tuberosa n. comb. from the Rupelian (Stampian) of the Aquitaine Basin. We propose an age of 27.82 Ma (Rupelian/ Chattian transition) for the node calibration.

Bursa, under the definition suggested in this paper, could be calibrated by the specimen resembling $B$. rosa from middle-late Miocene of Citalahab, West Java mentioned by Beu (2005: fig. 33). He attributed this specimen to $B$. rosa. Indeed, this specimen bears the long tubular posterior siphonal canal characteristic of the genus, but it is far less warty and could warrant erecting a new species, becoming thus the oldest species of all Bursa s.s. We propose an age of $9 \mathrm{Ma}$.

All the species of the former Bursa granularis complex (Sanders et al. 2017) could have their clade calibrated by the three specimens from Citalahab, West Java attributed by Beu (2005) to B. granularis, with an age of $9 \mathrm{Ma}$ as for Bursa s.s. This calibration should not be blindly trusted, because we have not seen the specimens and they were not figured by Beu (2005). The relationship of $B$. landaui to this clade remains too uncertain to be used as a calibration.

The genus Marsupina could be calibrated by the Shoal river formation specimen (USNM 647109), middle Miocene, figured by Beu (2010: pl. 9, fig. 6). This juvenile specimen strikingly resembling $M$. bufo, but has a more coarsely sculptured shell than later specimens of Marsupina, too much so to be conspecific. We propose an age of $14 \mathrm{Ma}$ for the calibration of crown Marsupina.

Strong et al.(2019) proposed to use the large specimen of Tutufa sp. Looking a lot like T. bubo figured by Tomida et al. (2013) as a calibration point for the genus Tutufa, calibrated at $13.5 \mathrm{Ma}$. We follow their recommendation.

No other node could be calibrated easily based on what we know currently of the systematics of Bursidae.

\section{TIMING OF DIVERSIFICATION OF BURSIDAE BASED ON THE FOSSIL RECORD}

Providing a scenario explaining the diversification of a highly dispersive family like the Bursidae is not an easy task, especially without a proper phylogenetic context. What we can say, however, is that the diversification of the Bursidae happened in three phases (Fig. 8).

Strong et al. (2018) estimated (with very low support regarding its relationship with its sister family) the origin of the family at around $113 \mathrm{Ma}$ but, as stated above, we have no trace of morphologically recognizable bursids prior to the middle Eocene (40 Ma) Peruvian fauna. Following this record there is no other trace of Bursidae in the Paleogene. A possible explanation of this lack of fossils is a general diminution of fossil-rich (unlithified) marine outcrops in the late Paleogene (Hendy 2011). This tendency dramatically shifts in the Neogene, as we found an already well diversified fauna throughout the lower Miocene Tethyan realm. 


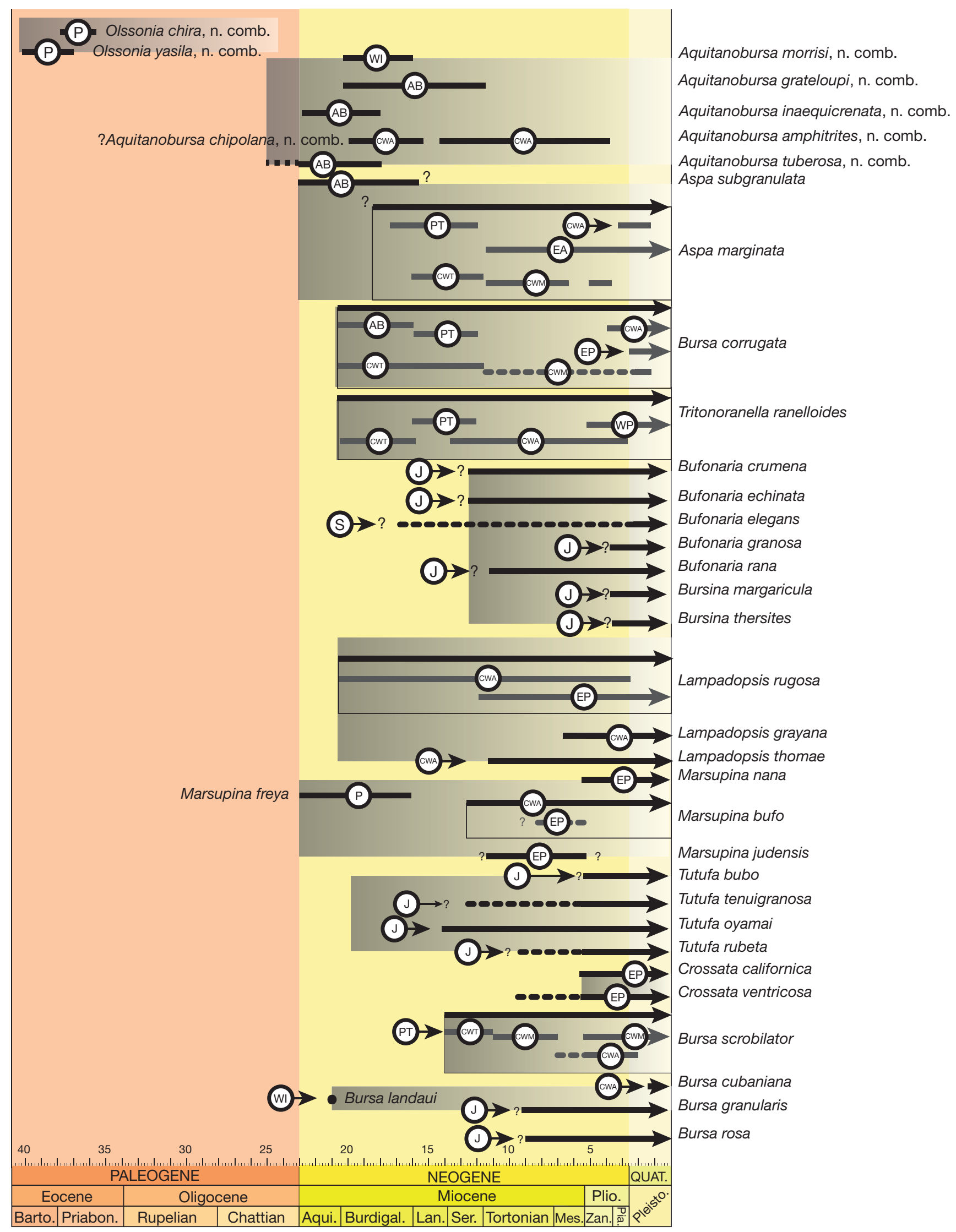

FIG. 8. - Stratigraphic range of the extinct and extant Bursidae. Black arrows indicate total stratigraphic range; grey arrows indicate regional stratigraphic range. Abbreviations: P, Peru; WI, Western Indian Ocean; AB, Aquitaine Basin; CWA, Caribbean, Western Atlantic Ocean; PT, Paratethys, CWT: Central Western Tethys; EA, Eastern Atlantic; CWM, Central Western Mediterranean; WP, Western Pacific Ocean; J, Java, Indo-Pacific; S, Sumatra, Indo-Pacific; EP, Eastern Pacific Ocean. Grey squares regroup accepted genera and putative genera within Bursa. 
In the west (Aquitaine Basin) most species of the genus Aquitanobursa n. gen., Aspa subgranulata and Bursa corrugata occur. In the "Mediterranean region" (sensu Harzhauser et al. 2002) Bursa corrugata and Bursa ranelloides occur. The presence of $B$. corrugata in both regions is a clear indication of a connection between the westernmost Tethys and the Atlantic. In the Eastern Proto-Indo-West-Pacific region, Bursidae are represented by Aquitanobursa morrisi n. comb. in the north (Pakistan) and by Bursa landaui in the southwest (Tanzania). The arrival of A. morrisi n. comb. in the Proto-Indo-West-Pacific region was most certainly through the Tethys, as most of the species of the genus are found in the Aquitaine Basin. On the other hand, the arrival $B$. landaui in the region is more difficult to explain.

The next phase of diversification happened during the middle Miocene with the closure of the Tethys Ocean in the east. Following this closure, we observed a relocation of the main coral biodiversity hotspot from the Mediterranean to the present-day coral triangle (Leprieur et al. 2016). This hot spot shift could explain the radiation of the coral-dependent bursids (Tutufa, Bufonaria, Bursa s.s.). An eastward colonization of most of those species is probable, although some genera (e.g. Lampadopsis) possibly arrived from the Pacific.

In the west, also during the middle Miocene, Aspa marginata entered the Eastern Atlantic and Lampadopsis rugosa entered the Pacific Ocean from the Caribbean. The genus Aquitanobursa n. gen. entered the Western Atlantic (A. amphitrites n. comb.) and the genus Marsupina appeared. In the Proto-Mediterranean Atlantic region the species Bursa scrobilator appeared.

The high species-level diversity of tonnoideans in general during the middle Miocene was already pointed out by Landau et al.(2009).

At the Miocene-Pliocene transition we see the appearance of the last currently admitted genera: Bursina in the Indo-Pacific and Crossata in western America (there is an unconfirmed occurrence of Crossata in the middle Miocene (Beu 2010; Powell \& Berschauer 2017).

Following the Messinian salinity crisis in the Mediterranean Sea, we observe the return of Bursa scrobilator to this domain. In the Recent fauna it is the only bursid species in the Mediterranean. Bursa corrugata returned briefly as well, but disappeared from the Mediterranean during the Pleistocene (Landau et al. 2009). It was also during the Pliocene that $B$. corrugata entered the western Atlantic, from which it reached the Eastern Pacific during the Pleistocene (Beu 2010). Aspa marginata reappeared briefly in the Mediterranean at the beginning of the Pliocene and reached its maximum geographic extension during the late Pliocene/early Pleistocene by entering the Western Atlantic. At present it occurs only in the Eastern Atlantic and at some mid-Atlantic islands.

\section{CONCLUDING REMARKS}

Dating biological events such as diversification or speciation in the fossil record remain a daunting task without a proper phylogenetic background, at least as much so as dating phylogenetic trees without proper fossil data. For this reason, reviews such as this one are paramount in order to understand the paleobiodiversity of a taxonomic group reliably. We followed as much as possible the recommendations of Parham et al. (2012) by systematically referring to the literature and by providing characters linking the fossils to extant clades and providing institution specimen numbers when possible. We hope the calibrations provided here will help unveil the Paleogene diversification pattern of the Bursidae, a period from which few fossils are known.

\section{Acknowledgements}

This project was supported by the Labex BCDiv "Diversités biologiques et culturelles" funded by the CNRS, MNHN, ANR, Sorbonne Université, IRD and EPHE. We thank Erica Clites (UCMP) for the loan and the photos of the Olequahia material. For providing pictures we are very grateful to Leslie Skibinski (PRI), Philippe Loubry (MNHN) and Alexandre Lardeur. We are grateful to Pierre Lozouet (MNHN) for the donation of the Palaeogene material of the Aquitaine Basin. We are grateful to Alan Beu (GNS Sciences, Lower Hutt, New Zealand) and Bernard Landau (Naturalis Biocenter, Leiden, The Netherlands) for their fruitful comments. For curation of the MNHN.F material we thank Jean-Michel Pacaud (MNHN).

\section{REFERENCES}

AdegoKe O. S. 1977. - Stratigraphy and paleontology of the Ewekoro formation (Paleocene) of southwestern Nigeria. Bulletins of American Paleontology 71 (295): 1-279. https://biodiversitylibrary. org/page/10696713

AlBI I. 2002. - Does the morphology of Pleistocene specimens of Crossata californica (Hinds, 1843) elucidate evolutionary patterns? The Festivus 34 (3): 31-42.

BALUK W. 1995. - Middle Miocene (Badenian) gastropods from Korytnica, Poland. Part II. Acta Geologica Polonica 45 (3-4): 1-255.

BELlardi L. 1873. - I molluschi dei terreni Terziarii del Piemonte e della Liguria. Part 1: Cephalopoda. Pteropoda. Heteropoda. Gasteropoda (Muricidae e Tritonidae). Memorie della Reale Accademia delle Scienze di Torino ser. 2, 27: 33-294. https:// biodiversitylibrary.org/page/12135674

BEU A. G. 1981. - Australian gastropods of the family Bursidae. Part 1. The families of Tonnacea, the genera of Bursidae, and revision of species previously assigned to Tutufa Jousseaume, 1881. Records of the Australian Museum 33: 248-324. https:// doi.org/10.3853/j.0067-1975.33.1980.200

BEU A. G. 1987. - Taxonomy of gastropods of the families Ranellidae (= Cymatiidae) and Bursidae. Part 2. Descriptions of 14 new modern Indo-West Pacific species and subspecies, with revisions of related taxa. New Zealand Journal of Zoology 13: 273-355. https://doi.org/10.1080/03014223.1986.10422668

BEU A. G. 1988. - Taxonomy of gastropods of the families Ranellidae (= Cymatiidae) and Bursidae. Part 5. Early history of the families, with four new genera and recognition of the Family Personidae, in Grant-Mackie J. A., Masuda K., Mori K. \& Ogasawara K. (eds), Professor Tamio Kotaka Commemorative Volume on Molluscan Paleontology. Saito Ho-on Kai, Special Publication No. 2, Sendai: 69-96.

BEU A. G. 1998. — Résultats des Campagnes MUSORSTOM volume 19. Indo-West Pacific Ranellidae, Bursidae and Personidae (Mollusca: Gastropoda), a monograph of the New Caledonian fauna and revisions of related taxa. Muséum national d'Histoire naturelle, Paris, 255 p. (Mémoires du Muséum national d'Histoire naturelle; 178). 
BEU A. G. 2005. - Neogene fossil tonnoidean gastropods of Indonesia. Scripta Geologica 130: 1-186.

BEU A. G. 2010. - Neogene tonnoidean gastropods of tropical and South America; a contribution to the Dominican Republic and Panama Paleontology projects and uplift of the Central American Isthmus. Bulletins of American Paleontology 377-378: 1-550.

Castelin M., Lorion J., Brisset J., Cruaud C., Maestrati P., UTGE J. \& SAmAdi S. 2012. - Speciation patterns in gastropods with long-lived larvae from deep-sea seamounts. Molecular Ecology 21 (19): 4828-4853. https://doi.org/10.1111/ j.1365-294X.2012.05743.x

Cossmann M. \& Peyrot A. 1924. - Conchologie néogénique de l'Aquitaine (Suite). Actes de la Société linnéenne de Bordeaux 75 (3): 193-318. https://biodiversitylibrary.org/page/32207388

D'ARChiaC A. \& HAIME J. 1853. - Description des animaux fossiles du groupe nummulitique de l'Inde. Gide et J. Baudry, Paris, 148 p. https://gallica.bnf.fr/ark:/12148/bpt6k6516664j/f13.image

Denniston R. F., Asmerom Y., Polyak V. Y., MCNeill D. F., KLAus J. S., Cole P. \& BudD A. F. 2008. — Caribbean chronostratigraphy refined with U-Pb dating of a Miocene coral. Geology 36 (2): 151-154. https://doi.org/10.1130/G24280A.1

Donoghue P. C. J. \& Benton M. J. 2007. — Rocks and clocks: calibrating the Tree of Life using fossils and molecules. Trends in Ecology and Evolution 22 (8): 424-431. https://doi.org/10.1016/j. tree.2007.05.005

Douzery E. J., Delsuc F. \& Philippe H. 2006. — Les datations moléculaires à l'heure de la génomique. Médecine/sciences 22 (4): 374-380. https://doi.org/10.1051/medsci/2006224374.

EXPEDiTiOns MUSÉUM 2018. — Expédition MD208 (Walters Shoal), https://expeditions.mnhn.fr/campaign/md208 (waltersshoal) (Accessed 19 September 2018).

FaURby S., EiserhardT W. L. \& SvenNing J. C. 2016. — Strong effects of variation in taxonomic opinion on diversification analyses. Methods in Ecology and Evolution 7 (1): 4-13. https://doi. org/10.1111/2041-210X.12449

GARDNER J. R. 1947. - The Molluscan Fauna of the Alum Bluff Group of Florida. United States Geological Survey Professional Paper 142A-H: 1-709. https://doi.org/10.3133/pp142A

GÉLY J. P. 1996. - Le Lutétien du bassin parisien: de l'analyse séquentielle haute résolution à la reconstitution paléogéographique. Bulletin d'Information du Bassin de Paris 34 (2): 3-27.

GiRiBET G. 2015. - Morphology should not be forgotten in the era of genomics - a phylogenetic perspective. Zoologischer Anzeiger-A Journal of Comparative Zoology 256: 96-103. https://doi. org/10.1016/j.jcz.2015.01.003

Gradstein F. M., OGG J. G., Schmitz M. \& OgG G. 2012. - The Geologic Time Scale 2012. First Edition. Elsevier, New York, 1176 p.

GratelOup J. P. S. DE 1833. - Tableau des coquilles fossiles qu'on rencontre dans les terrains calcaire tertiaires (faluns) des environs de Dax, département des Landes. Actes de la Société linnéenne de Bordeaux 6: 159-164. https://biodiversitylibrary. org/page/32986064

GRATELOUP J. P. S. de 1845. - Conchyliologie fossile des terrains tertiaires du Bassin de l'Adour (environ de Dax). Tome 1. Univalves. Lafargue, Bordeaux, pls 1, 3, 5-10 and 12-48.

Harzhauser M., Piller W. E. \& Steininger F. F. 2002. — CircumMediterranean Oligo-Miocene biogeographic evolution - the gastropods' point of view. Palaeogeography, Palaeoclimatology, Palaeoecology 183 (1-2): 103-133. https://doi.org/10.1016/ S0031-0182(01)00464-3

HarZHAuser M. 2009. - Aquitanian gastropods of coastal Tanzania and their biogeographic implications for the early western Indo-Pacific. Palaeontographica Abteilung A289: 123-156. https:// doi.org/10.1127/pala/289/2009/123

Harzhauser M., Reuter M., Piller W. E., Berning B., Kroh A. \& MANDIC O. 2009. — Oligocene and Early Miocene gastropods from Kutch (NW India) document an early biogeographic switch from Western Tethys to Indo-Pacific. Palaontologische Zeitschrift
83 (3): 333-372. https://doi.org/10.1007/s12542-009-0025-5 Hendy A. J. W. 2011. - Taphonomic Overprints on Phanerozoic Trends in Biodiversity: Lithification and Other Secular Megabiases, in Allison P. A. \& BotTjer D. J. (eds), Taphonomy. Aims \& Scope Topics in Geobiology 32: 19-77. https://doi. org/10.1007/978-90-481-8643-3_2

Ho S. Y. W. \& PHILlips M. J. 2009. - Accounting for calibration uncertainty in phylogenetic estimation of evolutionary divergence times. Systematic Biology 58 (3): 367-380. https://doi. org/10.1093/sysbio/syp035

Houbrick J. R. \& FreTTER V. 1969. - Some aspects of the functional anatomy and biology of Cymatium and Bursa. Journal of Molluscan Studies 38 (5): 415-429. https://doi.org/10.1093/ oxfordjournals.mollus.a065061

KASE T. 1984. - Early Cretaceous marine and brackish-water Gastropoda from Japan. National Science Museum Monographs 1: 1-189.

Landau B., Beu A. G. \& Marquet R. 2004. - The Early Pliocene Gastropoda (Mollusca) of Estepona, Southern Spain. Part 5: Tonnoidea, Ficoidea. Palaeontos 5: 35-102.

Landau B., Harzhauser M. \& BeU A. G. 2009. - A Revision of the Tonnoidea (Caenogastropoda, Gastropoda) from the Miocene Paratethys and their palaeobiogeographic implications. Jahrbuch Der Geologischen Bundesanstalt 149: 61-109.

Landau B., Da Silva C. M. \& Mayoral E. 2011. - The lower Pliocene gastropods of the Huelva sands formation, Guadalquivir basin, southwestern Spain. Palaeoscripta (Mortsel) 4: 1-90.

Leprieur F., Descombes P., Gaboriau T., Cowman P. F., Parravicini V., Kulbicki M., Melián C. J., Santana C. N. De, Heine C., Mouillot D., Bellwood D. R. \& Pellissier L. 2016. — Plate tectonics drive tropical reef biodiversity dynamics. Nature Communications 7: 11461. https://doi.org/10.1038/ncomms11461

Lozouet P. 1997. - Le domaine atlantique européen au Cénozoïque moyen : diversité et évolution des gastéropodes. Thèse de doctorat du Muséum national d'Histoire naturelle, Paris, 309 p (unpublished).

LozOUET P. 1998. - Nouvelles espèces de gastéropodes (Mollusca: Gastropoda) de l'Oligocène et du Miocène inférieur de l'Aquitaine (Sud-Ouest de la France). Cossmanniana 5 (3-4): 61-102.

Lozouet P., Lesport J.-F. \& Renard P. 2001. - Révision des gastropoda (Mollusca) du Stratotype de l'Aquitanien. Cossmanniana (h.s. 3): 1-189.

MalATESTA A. 1974. - Malacofauna pliocenica Umbra. Memorie per Servire alla Carta Geologica d'Italia 13: 1-498.

MARKS J. G. 1951. - Miocene stratigraphy and paleontology of south-western Ecuador. Bulletins of American Paleontology 33 (139): 271-432. https://biodiversitylibrary.org/page/10644801

MARTIN K. 1883-1887. - Paleontologische Ergebnisse von Tiefbohrungen auf Java, nebst allgemeineren Studien über das Tertiär von Java, Timor und einiger anderer Inseln. Sammlungen des Geologischen Reichs-Museums in Leiden (series 1) 3: 1-380. http:// www.repository.naturalis.nl/record/509541

MerLE D. 2001. - The spiral cords and the internal denticles of the outer lip in the Muricidae: terminology and methodological comments. Novapex 2 (3): 69-91. http://www.biodiversitylibrary. org/page/42258207

MERLE D. 2005. - The spiral cords of the Muricidae (Gastropoda, Neogastropoda): importance of ontogenetic and topological correspondences for delineating structural homologies. Lethaia 38 (4): 367-379. https://doi.org/10.1080/00241160500355129

MERLE D. 2012. — Les Gastéropodes cénozoïques: caractères' radiations et biodiversité. Mémoire d'habilitation à diriger des recherches (HDR), Paris, 200 p.

OLSSON A. A. 1930. - Contributions to the Tertiary paleontology of northern Peru: Part 3, Eocene Mollusca. Bulletins of American Paleontology 17 (62): 1-96. https://biodiversitylibrary.org/page/32443820

Olsson A. A. 1932. - Contributions to the Tertiary paleontology of northern Peru: Part 5. The Peruvian Miocene. Bulletins of American Paleontology 19 (68): 1-272. https://biodiversitylibrary. $\mathrm{org} /$ page/32532230 
Olsson A. A. 1942. - Tertiary and Quaternary fossils from Burica Peninsula of Panama and Costa Rica. Bulletins of American Paleontology 27 (106): 1-106.

OrbignY A. d' 1852. — Prodrome de Paléontologie stratigraphique universelle des animaux mollusques $\&$ rayonnés. Vol. 3, Masson, Paris, 190 p. https://doi.org/10.5962/bhl.title. 45605

Parham J. F., Donoghue P. C. J., Bell C. J., Calway T. D., Head J. J., Holroyd P. A., Inoue J. G., Irmis R. B., Joyce W. J., Ksepka D. T., Patané J. S. L., Smith N. D., Tarver J. E., van Tuinen M., Yang Z., ANGIElCZYK K. D., Greenwood J. M., Hipsley C. A., Jacobs L., MaKovicky P. J., MÜlleR J., SMith K. T., TheOdor J. M.,. WARnOcK R. C. M. \& BenTON M. J. 2012. - Best practices for justifying fossil calibrations. Systematic Biology 61 (2): 346-359. https://doi.org/10.1093/sysbio/syr107

Powell II C. L. \& BerSCHAUER D. P. 2017. - Crossata (Gastropoda: Bursidae) in the eastern Pacific: a morphologic and paleontologic perspective. The Festivus 49 (3): 179-198.

RIEDEL F. 1995. - An outline of cassoidean phylogeny (Mollusca, Gastropoda). Mededelingen van de Werkgroep voor Tertiaire en Kwartaire Geologie 32 (4): 97-132.

RobBa E. 1996. - The Rembangian (Middle Miocene) molluskfauna of Java, Indonesia. I. Archaeogastropoda. Rivista Italiana di Paleontologia e Stratigrafia 102 (2): 267-292. https://doi. org/10.13130/2039-4942/5251

Sanders M. T., Merle D., Bouchet P., Castelin M., Beu A. G., SAMAdi S. \& PuILlandre N. 2017. - One for each ocean: revision of the Bursa granularis species complex (Gastropoda: Tonnoidea: Bursidae). Journal of Molluscan Studies 83 (4): 384-398. https://doi.org/10.1093/mollus/eyx029

Schmelz G. W. 1997. - Notes on the fauna of the Chipola Formation - XLI. A reexamination of Bursa (Mollusca: Gastropoda) from the Chipola Formation, with the description of a new species. Tulane Studies in Geology and Paleontology 30: 105-108.

SEYFried H., SPRECHMANN P. \& Aguilar T. 1985. - Sedimentología y paleoecología de un estuario del litoral pacifico del istmo centroamericano primordial (Mioceno medio, Costa Rica). Revista Geológica de America Central3: 1-68. https://doi.org/10.15517/rgac.v0i03.10489

Sharaf E. F., Boudagher-Fadel M. K., Simo J. A. \& Carroll A. R. 2005. - Biostratigraphy and strontium isotope dating of Oligocene-Miocene strata, East Java, In@donesia. Stratigraphy 2 (3): 1-18.

Solsona M. 1998. - Paleobiologia dels mesogasteràpodes del Plioce del Mediterrani nord-occidental. PhD Thesis, Barcelona, 540 p.
Spencer H. G., Willan R. C., Marshall B. \& Murray T. J. 2016. Checklist of the Recent Mollusca recorded from the New Zealand Exclusive Economic Zone. http://www.molluscs.otago.ac.nz/index. html (accessed 12 November 2018).

STERLI J., POL D. \& LAURIN M. 2013. - Incorporating phylogenetic uncertainty on phylogeny-based paleontological dating and the timing of turtle diversification. Cladistics 29 (3): 233-246. https:// doi.org/10.1111/j.1096-0031.2012.00425.x

Stone B. 1949. - Age of the Chira Group, northwestern Peru. Journal of Paleontology 23: 156-160. https://www.jstor.org/stable/1299690

Strong E. E., Colgan D. J., Healy J. M., Lydeard C., PonDER W. F. \& GLAubreChT M. 2011. - Phylogeny of the gastropod superfamily Cerithioidea using morphology and molecules. Zoological Journal of the Linnean Society 162 (1): 43-89. https:// doi.org/10.1111/j.1096-3642.2010.00670.x

Strong E. E., Puillandre N., Beu A. G., Castelin M. \& Bouchet P. 2018. - Frogs and tuns and tritons - A molecular phylogeny and revised family classification of the predatory gastropod superfamily Tonnoidea (Caenogastropoda). Molecular Phylogenetics and Evolution 130: 18-34. https://doi.org/10.1016/j. ympev.2018.09.016

TAYLOR J. D. 1978. - Habitats and diet of predatory gastropods at Addu Atoll, Maldives. Journal of Experimental Marine Biology and Ecology 31 (1): 83-103. https://doi.org/10.1016/00220981(78)90138-7

Tomida S., Kadota M. \& Hosoda E. 2013. - A fossil tropical giant gastropod Tutufa (Gastropoda: Bursidae) from the Miocene Yugashima Group of Izu Peninsula, central Japan. Bulletin of the Mizunami Fossil Museum 39: 65-68.

VOKES E. H. 1973. - Notes on the fauna of the Chipola FormationXIV. On the occurrence of Bursa (Mollusca: Gastropoda) with comments on the genus. Tulane Study in Geology and Paleontology 10 (2): 97-101.

VOKES E. H. 1997. - Notes on the fauna of the Chipola Formation - XLIII Additions to the molluscan fauna since 1947. Tulane Study in Geology and Paleontology 30: 211-216.

VRedenburg E. 1925. - Descriptions of Mollusca from the PostEocene Tertiary Formation of North-Western India. Memoirs of the Geological Survey of India 50: 1-96.

WORMS (WORLD REGISTER OF MARINE SPECIES) 2017. — http:// www.marinespecies.org/ (accessed 20 May 2018). 
APPENDIX 1. - First occurrence and last occurrence data for all species of Bursidae. N.A., not applicable.

\begin{tabular}{|c|c|c|c|c|c|c|c|c|}
\hline Species & First occurrence & Formation & $\begin{array}{l}\text { Reference } \\
\text { to the } \\
\text { occurrence }\end{array}$ & $\begin{array}{l}\text { Reference } \\
\text { to the } \\
\text { e stratigraphy }\end{array}$ & $\begin{array}{l}\text { Last } \\
\text { yoccurrence }\end{array}$ & Formation & $\begin{array}{l}\text { Reference } \\
\text { for the } \\
\text { occurrence }\end{array}$ & $\begin{array}{l}\text { Reference } \\
\text { for the } \\
\text { stratigraphy }\end{array}$ \\
\hline $\begin{array}{l}\text { Aquitanobursa } \\
\text { chipolana } \\
\text { n. comb. }\end{array}$ & Burdigalian & $\begin{array}{l}\text { Chipola } \\
\text { formation, } \\
\text { Florida }\end{array}$ & Beu 2010 & Beu 2010 & Burdigalian & $\begin{array}{l}\text { Chipola } \\
\text { formation, } \\
\text { Florida }\end{array}$ & Beu 2010 & Beu 2010 \\
\hline $\begin{array}{l}\text { Aquitanobursa } \\
\text { amphitrites } \\
\text { n. comb. }\end{array}$ & Tortonian & $\begin{array}{l}\text { Buenevara } \\
\text { Adentro beds, } \\
\text { Venezuela }\end{array}$ & Beu 2010 & Beu 2010 & Zanclean & $\begin{array}{l}\text { Gurabo } \\
\text { Formation, } \\
\text { Dominican } \\
\text { republic }\end{array}$ & Beu 2010 & Beu 2010 \\
\hline $\begin{array}{l}\text { Aquitanobursa } \\
\text { inaequicrenata } \\
\text { n. comb. }\end{array}$ & $\begin{array}{l}\text { Lower } \\
\quad \text { Burdigalian }\end{array}$ & $\begin{array}{l}\text { Le Peloua, } \\
\text { Aquitaine } \\
\text { Basin, France }\end{array}$ & $\begin{array}{l}\text { Cossmann \& } \\
\text { Peyrot } \\
1924\end{array}$ & $\begin{array}{l}\text { Lozouet } \\
1998\end{array}$ & $\begin{array}{l}\text { Lower } \\
\quad \text { Burdigalian }\end{array}$ & $\begin{array}{l}\text { Le Peloua, } \\
\text { Aquitaine } \\
\text { Basin, France }\end{array}$ & $\begin{array}{c}\text { Lozouet } \\
1997\end{array}$ & $\begin{array}{c}\text { Lozouet } \\
1998\end{array}$ \\
\hline $\begin{array}{l}\text { Aquitanobursa } \\
\text { morrisi } \\
\text { n. comb. }\end{array}$ & Burdigalian & $\begin{array}{l}\text { Calcaire grossier } \\
\text { de la chaine } \\
\text { d'Hala, } \\
\text { Pakistan }\end{array}$ & $\begin{array}{l}\text { D'Archiac \& } \\
\text { Haime } \\
1853\end{array}$ & $\begin{array}{l}\text { Vredenburg } \\
1925 \\
\text { Harzhauser } \\
\text { et al. } 2009\end{array}$ & Burdigalian & $\begin{array}{l}\text { Calacaire grossier } \\
\text { dela chaine } \\
\text { d'Hala }\end{array}$ & $\begin{array}{l}\text { R'Archiac \& } \\
\text { Haime } \\
1853\end{array}$ & $\begin{array}{l}\text { Vredenburg } \\
1925 \\
\text { Harzhauser } \\
\text { et al. } 2009\end{array}$ \\
\hline $\begin{array}{l}\text { Aquitanobursa } \\
\text { tuberosa } \\
\text { n. comb. }\end{array}$ & Rupelian & $\begin{array}{l}\text { Aquitaine basin, } \\
\text { France }\end{array}$ & $\begin{array}{c}\text { Lozouet } \\
1998\end{array}$ & $\begin{array}{c}\text { Lozouet } \\
1998\end{array}$ & $\begin{array}{l}\text { Lower } \\
\quad \text { Burdigalian }\end{array}$ & Aquitaine basin & $\begin{array}{c}\text { Lozouet } \\
1998\end{array}$ & $\begin{array}{c}\text { Lozouet } \\
1998\end{array}$ \\
\hline $\begin{array}{l}\text { Bufonaria } \\
\text { crumena }\end{array}$ & $\begin{array}{l}\text { Middle Miocene } \\
\text { (early } \\
\text { Preangerian) }\end{array}$ & $\begin{array}{c}\text { Robba's locality } \\
\text { ClJ1, Cijarian, } \\
\text { western Java }\end{array}$ & Beu 2005 & Beu 2005 & Extant & N.A. & N.A. & N.A. \\
\hline $\begin{array}{l}\text { Bufonaria } \\
\text { echinata }\end{array}$ & $\begin{array}{l}\text { Middle Miocene } \\
\text { (early } \\
\text { Preangerian) }\end{array}$ & $\begin{array}{c}\text { Robba's locality } \\
\text { CIJ1, Cijarian, } \\
\text { western Java }\end{array}$ & Beu 2005 & Beu 2005 & Extant & N.A. & N.A. & N.A. \\
\hline Bufonaria elegans & $\begin{array}{l}\text { Pleistocene (Early } \\
\text { Miocene) }\end{array}$ & $\begin{array}{l}\text { Nias Island, } \\
\text { Sumatra } \\
\text { (Pakistan) }\end{array}$ & Beu 2005 & Beu 2005 & Extant & N.A. & N.A. & N.A. \\
\hline $\begin{array}{l}\text { Bufonaria } \\
\text { granosa }\end{array}$ & $\begin{array}{l}\text { Late Pliocene } \\
\quad \text { (Piacenzian?) }\end{array}$ & $\begin{array}{l}\text { Kalibeng layers, } \\
\text { Sangiran, } \\
\text { central Java }\end{array}$ & Beu 2005 & Beu 2005 & Extant & N.A. & N.A. & N.A. \\
\hline Bufonaria rana & Late Miocene & $\begin{array}{l}\text { Kendeng beds, } \\
\text { Jave }\end{array}$ & Beu 2005 & $\begin{array}{l}\text { Robba } 1996 \\
\text { Sharaf } \\
\text { et al. } \\
2005\end{array}$ & 6 Extant & N.A. & N.A. & N.A. \\
\hline Bursa corrugata & Burdigalian & $\begin{array}{l}\text { Aquitaine basin, } \\
\text { France }\end{array}$ & $\begin{array}{l}\text { Cossmann \& } \\
\text { Peyrot } \\
1924\end{array}$ & $\begin{array}{l}\text { Landau } \\
\text { et al. } \\
2009\end{array}$ & Extant & N.A. & N.A. & N.A. \\
\hline Bursa cubaniana & Pleistocene & $\begin{array}{l}\text { Various } \\
\text { formations } \\
\text { from Panama, } \\
\text { Cuba, } \\
\text { Dominican } \\
\text { republic and } \\
\text { Barbados }\end{array}$ & Beu 2010 & Beu 2010 & Extant & N.A. & N.A. & N.A. \\
\hline Bursa granularis & Late Miocene & $\begin{array}{l}\text { Citalahab, West } \\
\text { Java }\end{array}$ & Beu 2005 & Beu 2005 & Extant & N.A. & N.A. & N.A. \\
\hline $\begin{array}{c}\text { Aquitanobursa } \\
\text { grateloupi }\end{array}$ & Burdigalian & $\begin{array}{l}\text { Bordeau } \\
\text { surroundings, } \\
\text { Aquitaine } \\
\text { Basin, France }\end{array}$ & $\begin{array}{c}\text { d'Orbigny } \\
1852\end{array}$ & $\begin{array}{c}\text { d'Orbigny } \\
1852\end{array}$ & Serravallian & $\begin{array}{l}\text { Tauziets } \\
\text { Aquitaine } \\
\text { basin, France }\end{array}$ & $\begin{array}{c}\text { Lozouet } \\
1997\end{array}$ & $\begin{array}{c}\text { Lozouet } \\
1998\end{array}$ \\
\hline Bursa grayana & Messinian & $\begin{array}{l}\text { Cercado } \\
\text { formation, } \\
\text { Dominican } \\
\text { republic }\end{array}$ & Beu 2010 & Beu 2010 & Extant & N.A. & N.A. & N.A. \\
\hline Bursa landaui & Aquitanian & $\begin{array}{l}\text { Ras Tipuli } \\
\text { Tanzania }\end{array}$ & $\begin{array}{l}\text { Harzhauser } \\
2009\end{array}$ & $\begin{array}{l}\text { Harzhauser } \\
2009\end{array}$ & Aquitanian & $\begin{array}{l}\text { Ras Tipuli } \\
\text { Tanzania }\end{array}$ & $\begin{array}{l}\text { Harzhauser } \\
2009\end{array}$ & $\begin{array}{l}\text { Harzhauser } \\
2009\end{array}$ \\
\hline Bursa rosa & Late Miocene & $\begin{array}{l}\text { Citalahab, West } \\
\text { Java }\end{array}$ & Beu 2005 & Beu 2005 & Extant & N.A. & N.A. & N.A. \\
\hline Bursa rugosa & Burdigalian & $\begin{array}{l}\text { Cantaure, } \\
\text { Venezuela }\end{array}$ & Beu 2010 & Beu 2010 & Extant & N.A. & N.A. & N.A. \\
\hline Bursa scrobilator & $\begin{array}{l}\text { Langhian/Serra- } \\
\text { vallian }\end{array}$ & $\begin{array}{l}\text { Paratethys } \\
\text { Austria and } \\
\text { Poland }\end{array}$ & $\begin{array}{l}\text { Landeau } \\
\text { et al. } \\
2004\end{array}$ & Baluk 1995 & Extant & N.A. & N.A. & N.A. \\
\hline $\begin{array}{l}\text { Lampadopsis } \\
\text { thomae }\end{array}$ & Burdigalian & $\begin{array}{l}\text { Chipola } \\
\text { formation, } \\
\text { Florida }\end{array}$ & Beu 2010 & $\begin{array}{c}\text { Tulane fossil } \\
\text { localities }\end{array}$ & il Extant & N.A. & N.A. & N.A. \\
\hline
\end{tabular}


APPENDIX 1. - Continuation.

\begin{tabular}{|c|c|c|c|c|c|c|c|c|}
\hline Species & First occurrence & Formation & $\begin{array}{l}\text { Reference } \\
\text { to the } \\
\text { occurrence }\end{array}$ & $\begin{array}{l}\text { Reference } \\
\text { to the } \\
\text { stratigraphy }\end{array}$ & $\begin{array}{l}\text { Last } \\
\text { yoccurrence }\end{array}$ & Formation & $\begin{array}{l}\text { Reference } \\
\text { for the } \\
\text { occurrence }\end{array}$ & $\begin{array}{l}\text { Reference } \\
\text { for the } \\
\text { stratigraphy }\end{array}$ \\
\hline $\begin{array}{l}\text { Bursina } \\
\quad \text { margaricula }\end{array}$ & Pliocene & $\begin{array}{l}\text { Tjikeusik } \\
\text { [Cikeusik], } \\
\text { Java }\end{array}$ & Beu 2005 & Beu 2005 & Extant & N.A. & N.A. & N.A. \\
\hline $\begin{array}{l}\text { Crossata } \\
\text { ventricosa }\end{array}$ & Tortonian & $\begin{array}{l}\text { Tumbez Fm, } \\
\text { Quebrada } \\
\text { Tucillal, } \\
\text { Zorritos, Peru }\end{array}$ & $\begin{array}{l}\text { Olsson } \\
\text { 1932; Beu } \\
2010\end{array}$ & Olsson 1932 & 2Extant & N.A. & N.A. & N.A. \\
\hline Marsupina bufo & Serravallian & $\begin{array}{l}\text { Shoal River } \\
\text { formation, } \\
\text { Florida }\end{array}$ & Beu 2010 & $\begin{array}{c}\text { Gardner } \\
1947\end{array}$ & Extant & N.A. & N.A. & N.A. \\
\hline Marsupina freya & $\begin{array}{l}\text { Chattian/ } \\
\text { Aquitanian }\end{array}$ & $\begin{array}{l}\text { Malpais, SW } \\
\text { coast of } \\
\text { Nicoya } \\
\text { Peninsula, } \\
\text { Pacific Costa } \\
\text { Rica }\end{array}$ & Beu 2010 & Beu 2010 & $\begin{array}{l}\text { Burdigalian/ } \\
\text { Langhian }\end{array}$ & $\begin{array}{l}\text { Subibaya } \\
\text { Formation, } \\
\text { Progreso } \\
\text { Basin, SW } \\
\text { Ecuador }\end{array}$ & Beu 2010 & Beu 2010 \\
\hline $\begin{array}{r}\text { Marsupina } \\
\text { judensis }\end{array}$ & Late Miocene & $\begin{array}{l}\text { Punta Judas, } \\
40 \mathrm{~km} \text { WNW } \\
\text { of Quepos, } \\
\text { Pacific coast of } \\
\text { Costa Rica }\end{array}$ & Beu 2010 & Beu 2010 & Late Miocene & $\begin{array}{l}\text { Punta Judas, } \\
40 \mathrm{~km} \text { WNW } \\
\text { of Quepos, } \\
\text { Pacific coast of } \\
\text { Costa Rica }\end{array}$ & Beu 2010 & Beu 2010 \\
\hline Marsupina nana & Zanclean & $\begin{array}{l}\text { Charco Azul } \\
\text { Group, } \\
\text { Penita Fm, } \\
\text { Quebrada La } \\
\text { Penita, Burica } \\
\text { Peninsula, } \\
\text { Pacific coast of } \\
\text { Costa Rica }\end{array}$ & Beu 2010 & $\begin{array}{r}\text { Olsson } \\
1942\end{array}$ & Extant & N.A. & N.A. & N.A. \\
\hline $\begin{array}{l}\text { Olssonia chira } \\
\text { n. comb. }\end{array}$ & Priabonian & $\begin{array}{l}\text { Chira formation, } \\
\text { Quercotilla, } \\
\text { Peru }\end{array}$ & Olsson 1930 & Stone 1949 & Bartonian & $\begin{array}{l}\text { Chira Formation, } \\
\text { Quercotilla, } \\
\text { Peru }\end{array}$ & Olsson 1930 & OStone 1949 \\
\hline $\begin{array}{l}\text { Olssonia yasila } \\
\text { n. comb. }\end{array}$ & Bartonian & $\begin{array}{l}\text { talara formation, } \\
\text { Peru }\end{array}$ & Olsson 1930 & Olsson 1930 & 0Bartonian & $\begin{array}{l}\text { Talara Formation } \\
\text { Peru }\end{array}$ & Olsson 1930 & DOlsson 1930 \\
\hline Tutufa bubo & Late Miocene? & $\begin{array}{l}\text { Pendopo Oilfield, } \\
16 \mathrm{~km} \text { east of } \\
\text { Talang Akar, } \\
\text { Sumatra }\end{array}$ & Beu 2005 & Robba 1996 & 6 Extant & N.A. & N.A. & N.A. \\
\hline Tutufa oyamai & $\begin{array}{l}\text { Langhian/ } \\
\text { Serravallian }\end{array}$ & $\begin{array}{l}\text { Karas, Rembang, } \\
\text { Ngrayong } \\
\text { Formation, } \\
\text { Java }\end{array}$ & Beu 2005 & $\begin{array}{l}\text { Robba } \\
\text { 1996; } \\
\text { Sharaf } \\
\text { et al. } \\
2005\end{array}$ & Extant & N.A. & N.A. & N.A. \\
\hline Tutufa rubeta & Late Miocene & $\begin{array}{l}\text { Citalahab, West } \\
\text { Java }\end{array}$ & Beu 2005 & Beu 2005 & Extant & N.A. & N.A. & N.A. \\
\hline $\begin{array}{l}\text { Tutufa } \\
\text { tenuigranosa }\end{array}$ & Miocene & $\begin{array}{l}\text { Mount Butack, } \\
\text { Rembang, } \\
\text { central Java }\end{array}$ & Beu 2005 & Beu 2005 & Extant & N.A. & N.A. & N.A. \\
\hline $\begin{array}{l}\text { Aspa } \\
\quad \text { subgranulata }\end{array}$ & Rupelian & Gaas, Landes & Beu 2010 & Beu 2010 & $\begin{array}{l}\text { Middle } \\
\quad \text { Miocene }\end{array}$ & $?$ & $\begin{array}{l}\text { Landau } \\
\text { et al. } \\
2004\end{array}$ & $\begin{array}{l}\text { Landau } \\
\quad \text { et al. } 2004\end{array}$ \\
\hline Aspa marginata & Burdigalian & $\begin{array}{c}\text { Po valley and } \\
\text { Paratethys }\end{array}$ & $\begin{array}{l}\text { Landau } \\
\text { et al. } \\
2004 \text {, } \\
2009\end{array}$ & $\begin{array}{l}\text { Landau } \\
\text { et al. } \\
2004 \text {, } \\
2009\end{array}$ & Extant & N.A. & N.A. & N.A. \\
\hline
\end{tabular}

